
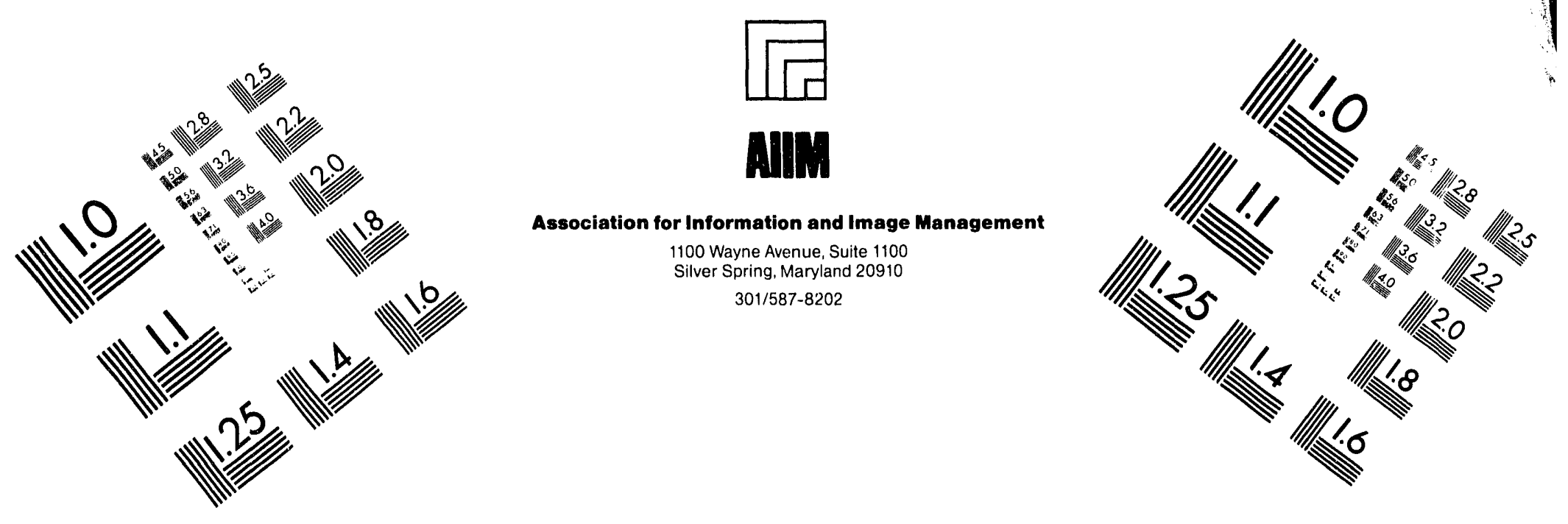

\title{
Centimeter
}

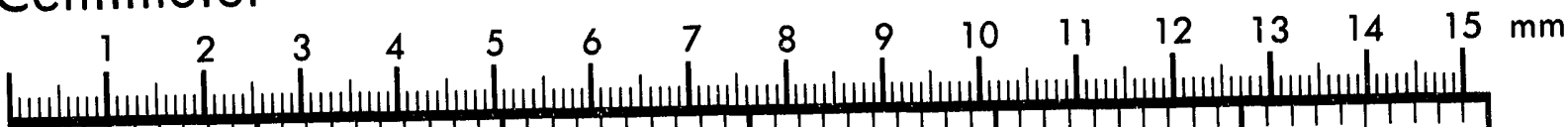

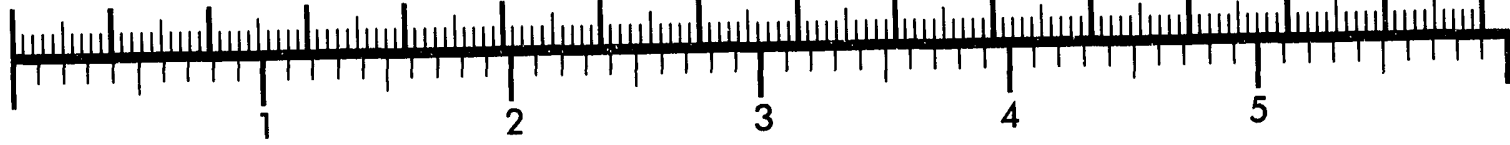
Inches
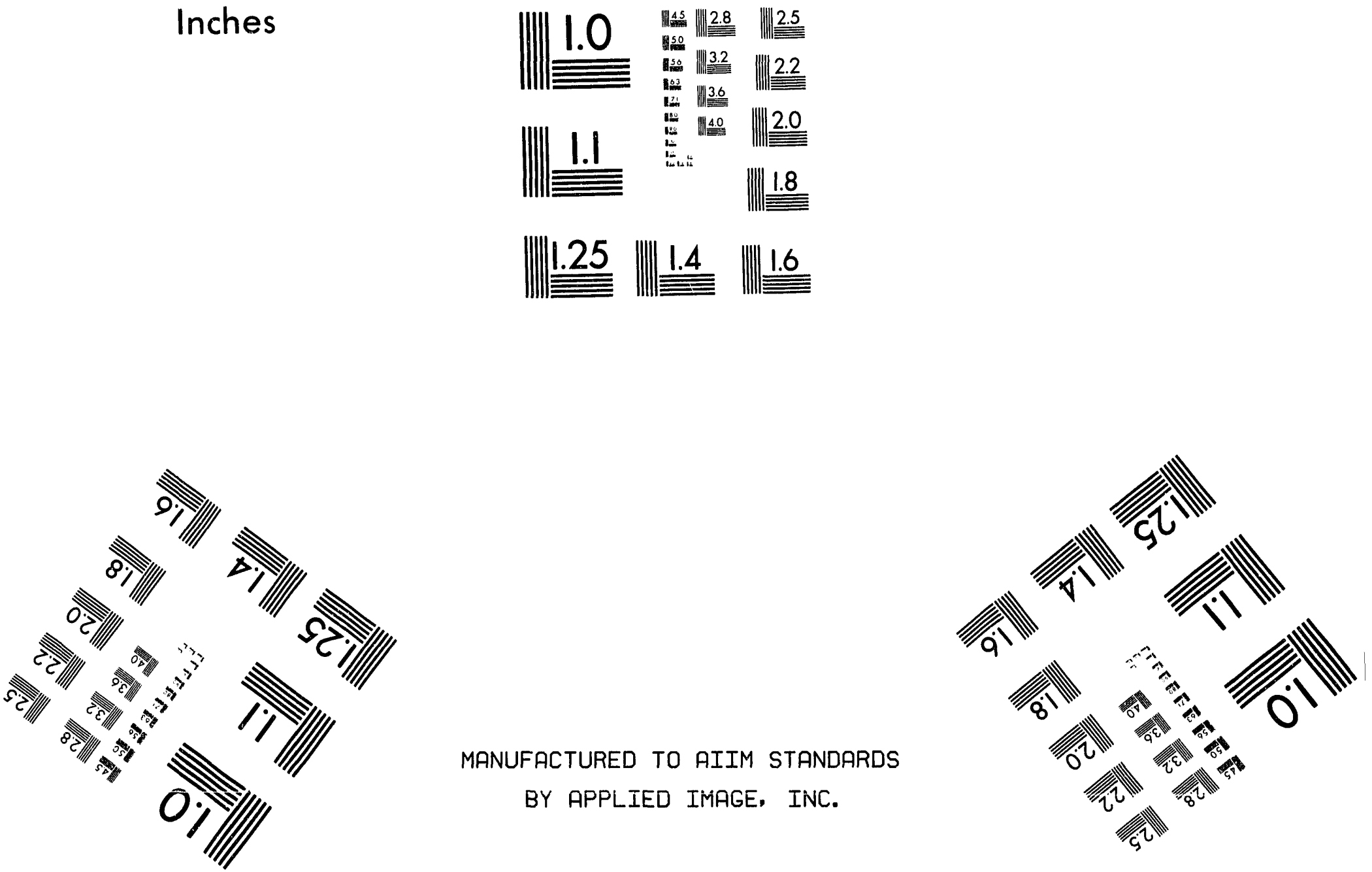

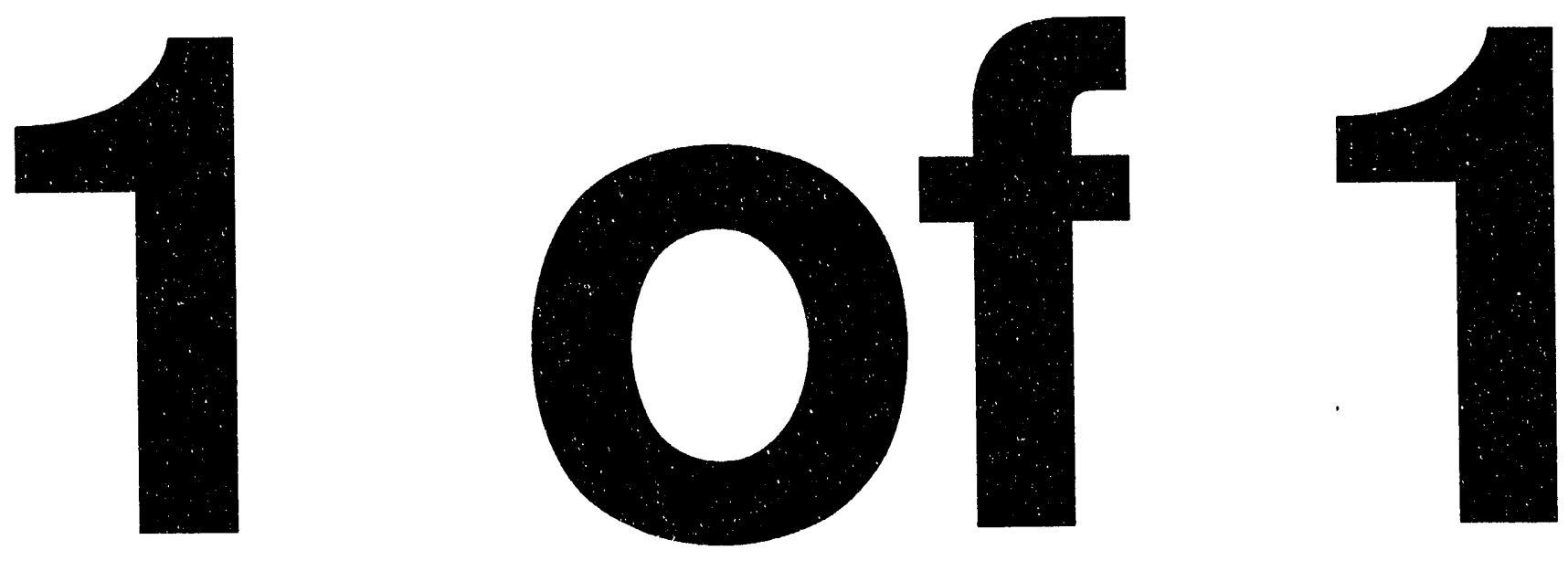


\section{RECENT ADVANCES IN ORDERED INTERMETALLICS}

C. T. LIU

Metals and Ceramics Division, Oak Ridge National Laboratory, Oak Ridge, TN 37831-6115

\section{ABSTRACT}

This paper briefly summarizes recent advances in intermetallic research and development. Ordered intermetallics based on aluminides and silicides possess attractive properties for structural applications at elevated temperatures in hostile environments; however, brittle fracture and poor fracture resistance limit their use as engineering materials in many cases. In recent years, considerable efforts have been devoted to the study of the brittle fracture behavior of intermetallic alloys; as a result, both intrinsic and extrinsic factors governing brittle fracture have been identified. Recent advances in first-principles calculations and atomistic simulations further help us in understanding atomic bonding, dislocation configuration, and alloying effects in intermetallics. The basic understanding has led to the development of nickel, iron, and titanium aluminide alloys with improved mechanical and metallurgical properties for structural use. Industrial interest in ductile intermetallic alloys is high, and several examples of industrial involvement are mentioned.

\section{INTRODUCTION}

Ordered intermetallics based on aluminides and silicides constitute a unique class of metallic materials for structural use at elevated temperatures in hostile environments. Their promising properties include excellent elevated-temperature strength, resistance to oxidation and corrosion, and relatively low density and high melting point [1-12]. However, most intermetallics exhibit britile fracture and low ductility at ambient temperatures, and poor fracture resistance and limited fabricability restrict their use as engineering materials in many cases. The recent search for new high-temperature materials has stimulated a great deal of interest in development of ordered intermetallics for structural use. The progress made during the past 10 years has been recorded in several proceedings and books:

1. High-Temperature Ordered Intermetallic Alloys I. II, II, and IV, ed. Koch et al., 1985; Stoloff et al., 1987; Liu et al., 1989; and Johnson et al., 1991; respectively [1-4];

2. High Temperature Aluminides and Intermetallics, ed. Whang et al., 1990 and 1992 [5,6];

3. Intermetallic Compounds - Structure and Mechanical Properties, ed. Izumi, 1991 [7];

4. Ordered Intermetallics_Physical Metallurgy and Mechanical Behavior, ed. Liu et al., 1992 [8];

5. Microstructure/Property Relationships in Titanium Aluminides and Alloys, ed. Kim and Boyer, 1991 [9];

6. The Deformation Behavior of Intermetallic Superlattice Compounds, Yamaguchi and Umakoshi, 1990 [10];

7. Ordered Intermetallics, Liu et al., 1990 [11]; and

8. Ordered Alloys, ed. Stoloff, 1984 [12].

At present, there is world-wide interest in ordered intermetallics; as a result, many new results have been generated each year. Because of page limitation, a systematic review of the recent progress on ordered intermetallics is not feasible in this brief paper. Consequently, this paper will include only some highlights of the recent progress made in understanding brittle fracture behavior and improving the mechanical properties of intermetallic alloys at ambient and elevated temperatures. Readers are urged to go over the invited papers in this MRS proceedings [13], which provide comprehensive reviews of recent progress in different alloy systems and property areas. A number of intermetallic systems have been developed to the stage where they are ready for engineering use, and examples of industrial interest and potential use of these intermetallics are also briefly mentioned in this paper.

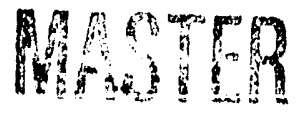




\section{IRON ALUMINIDES AND ENVIRONMENTAL EFFECTS}

Iron aluminides based on $\mathrm{Fe}_{3} \mathrm{Al}\left(\mathrm{DO}_{3}\right)$ and $\mathrm{FeAl}(\mathrm{B} 2)$ have excellent oxidation and corrosion resistance because they are capable of forming protective oxide scales at elevated temperatures in hostile environments [14]. In addition, these aluminides offer low material cost, low density, and conservation of strategic elements (such as chromium). The major drawbacks of the aluminides are their poor ductility and fracture resistance at ambient temperatures and their poor strength and creep resistance at temperatures above $600^{\circ} \mathrm{C}$. The aluminides were known to be brittle at room temperature for more than 40 years; however, the major cause of their brittleness was not identified until recently [15].

Recent studies have shown that $\mathrm{Fe}_{3} \mathrm{Al}$ and $\mathrm{FeAl}$ aluminides are intrinsically quite ductile and that the poor ductility commonly observed in air tests is caused mainly by an extrinsic effect-environmental embrittlement $[15,16]$. The effect of test environment on tensile properties is shown in Fig. 1 for FeAl containing 36.5 at. \% Al. The yield strength is insensitive to environment, and the ultimate tensile strength correlates v'ith the tensile elongation, which depends strongly on test environment. The aluminide had ductilities of $2 \%$ in air, $6 \%$ in vacuum, and $17.6 \%$ in dry oxygen. The water-vapor test confirmed the low ductility found in the air tests, indicating that moisture in air is the embrittling agent. The increase in ductility from 2 to $18 \%$ is accompanied by a change in fracture mode from transgranular cleavage in air to mainly grainboundary separation in dry oxygen. This observation suggests that cleavage planes in $\mathrm{FeAl}$ are more susceptible to embrittlement than are the grain boundaries.

Environmental embrittlement has been explained by the following chemical reaction:

$$
2 \mathrm{Al}+3 \mathrm{H}_{2} \mathrm{O} \rightarrow \mathrm{Al}_{2} \mathrm{O}_{3}+6 \mathrm{H} .
$$

The reaction of moisture in air with aluminum atoms at crack tips results in the generation of high-fugacity atomic hydrogen that rapidly penetrates into crack tips and causes severe embrittlement. The fact that the yield strength is insensitive to ductility and test environment is consistent with the mechanisms of hydrogen embrittlement observed in other ordered intermetallic alloys [17-25]. The highest ductility is generally obtained in dry oxygen environment (rather than in vacuum) because oxygen reacts with the aluminum to form aluminum oxide directly [26], thereby suppressing the moisture/aluminum reaction and the generation of atomic hydrogen in Eq. 1:

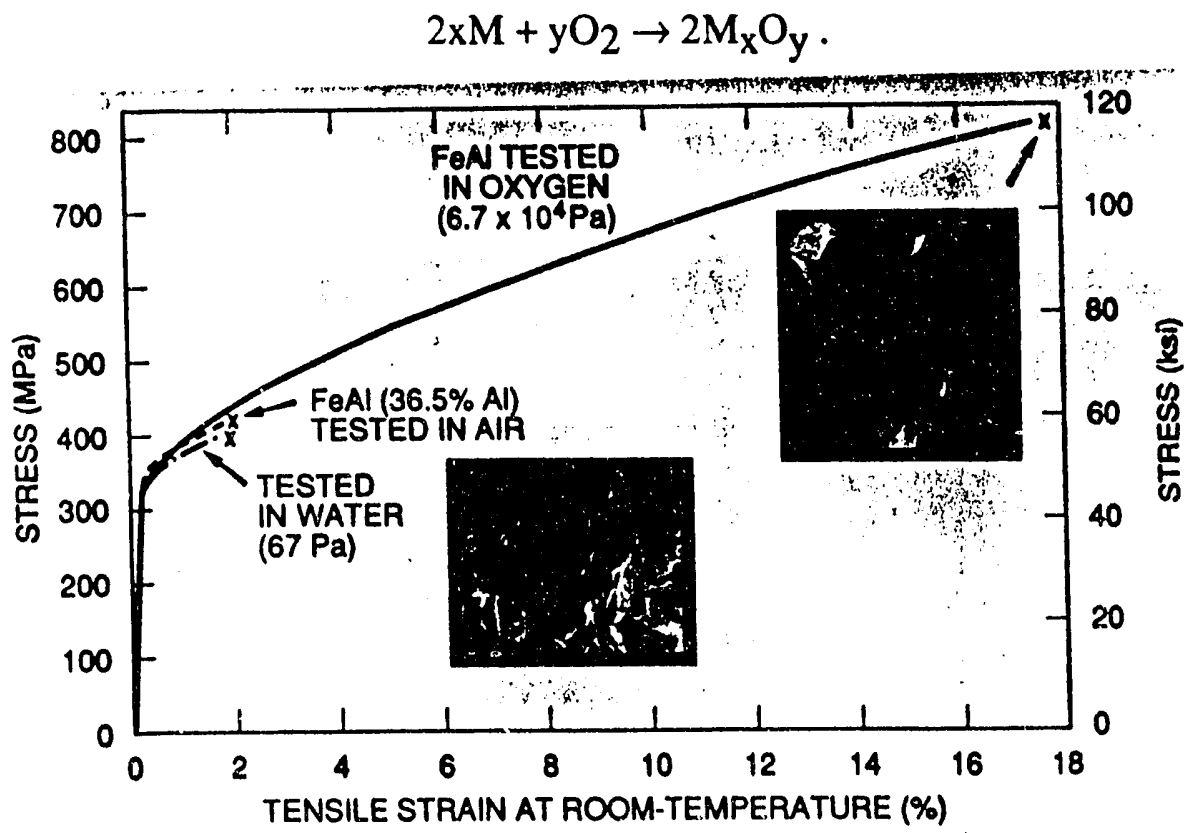

Fig. 1. Effect of test environment on the room-temperature ductility and fracture behavior of $\mathrm{FeAl}(36.5$ at. \% Al) [11]. 
It should be noted that the maximum degree of moisture-induced hydrogen embrittlement occurs around ambient temperatures [27]. At higher temperatures less hydrogen is concentrated at crack tips, and in situ protective oxide films can form more readily on specimen surfaces, while at lower temperatures the aluminum-moisture reaction is slowed, and the equilibrium moisture content in air also is lowered.

The environmental sensitivity of $\mathrm{FeAl}$ is markedly reduced when the aluminum concentration is higher than 38 at. \% [28-30]. For Fe-43 at. \% Al, the ductility is almost nil in air as well as in dry oxygen; all specimens fail intergranularly. The lack of an environmental effect is explained by the fact that grain boundaries in $\mathrm{FeAl}$ alloys with $\mathrm{Al}>38 \%$ are intrinsically brittle. Therefore, environmental embrittlement and intrinsic grain-boundary brittleness must both be recognized in order to establish strategies for reducing overall brittleness. It has been demonstrated that the intrinsic grain-boundary brittleness in FeAl, as well as other intermetallics, can be alleviated by microalloying with boron $[28,29]$, which tends to segregate to the boundaries and enhance their cohesive strength.

Similar air embrittlement has been observed in $\mathrm{Fe}_{3} \mathrm{Al}$ alloys [16,31-34]. The moistureinduced hydrogen affects not only tensile properties, but also the fatigue and crack growth behaviors [33]. Under cyclic loading conditions, vacuum or oxygen environments raise the fatigue threshold and reduce crack growth rates at ambient temperatures (Fig. 2).

The understanding of the cause of brittleness in $\mathrm{FeAl}$ and $\mathrm{Fe}_{3} \mathrm{Al}$ has led to new directions in the design of ductile iron-aluninide alloys. The schemes used to improve the ductility of the iron aluminides include $[14,35,36]$ :

(1) formation of protective oxide scales on surfaces by alloying with chromium and/or preoxidizing in air,

(2) refinement of grain structure by thermomechanical treatment;

(3) refinetnent of grain structure by second-phase particles, such as formation of zirconium borides and carbide by alloying with $\mathrm{Zr}, \mathrm{B}$, and $\mathrm{C}$;

(4) enhancement of grain-boundary cohesion by microalloying with boron; and

(5) reducing hydrogen solubility and diffusivity by alloying additions (possibly boron).

Figure 3 compares the tensile curve of binary $\mathrm{Fe}_{3} \mathrm{Al}$ with ductile $\mathrm{Fe}_{3} \mathrm{Al}(28$ at. \% $\mathrm{Al})$ alloys developed by both thermomechanical treatment and alloying additions [14]. The ductile $\mathrm{Fe}_{3} \mathrm{Al}$ alloys showed a high ductility of $16 \%$ when tested in air at room temperature. The strength of

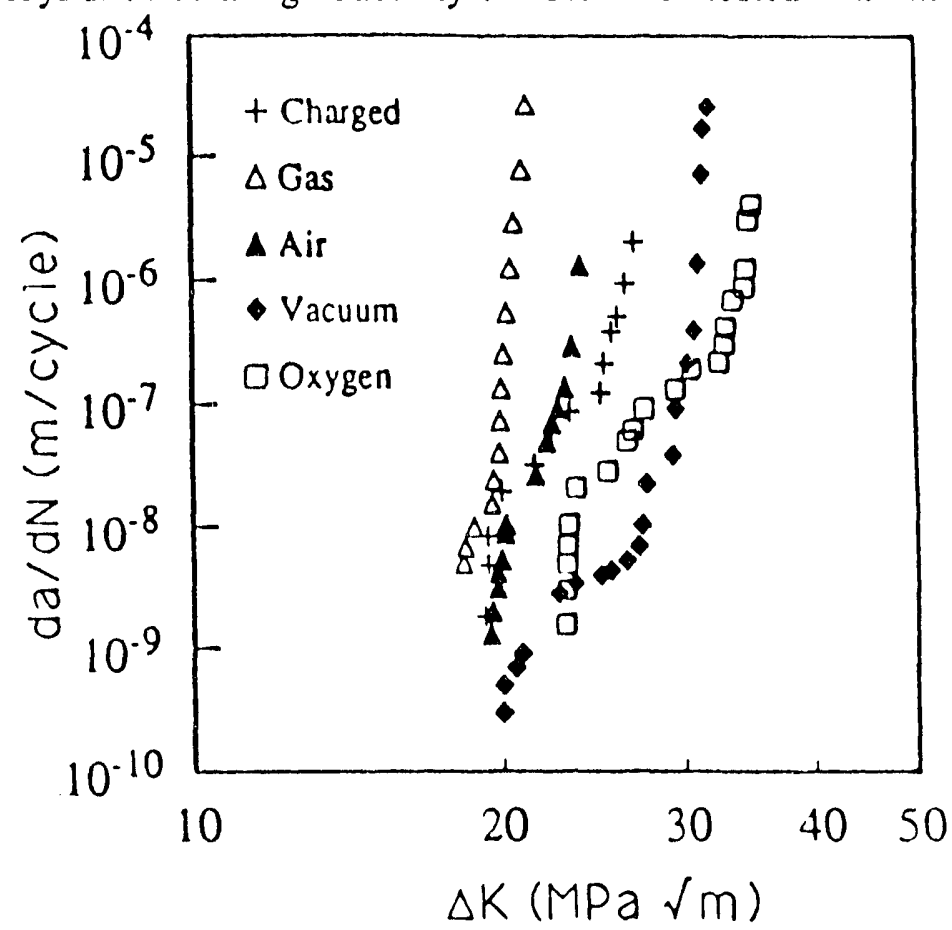

$\mathrm{Fe}_{3} \mathrm{Al}$ and $\mathrm{FeAl}$ alloys at elevated temperatures can be improved by alloying with $\mathrm{Mo}, \mathrm{Nb}$, and $\mathrm{Zr}$ $[14,36]$. The recent development of ductile and strong $\mathrm{Fe}_{3} \mathrm{Al}$ - and FeAl-base alloys is summarized in the paper by McKamey et al. [14] and the report by Liu et al. [36].

\section{Ni3AI AND GRAIN. BOUNDARY FRACTURE}

$\mathrm{Ni}_{3} \mathrm{Al}$ with the $\mathrm{Ll}_{2}$ structure is the most important strengthening constituent in nickel-base superalloys. This is because this aluminide has excellent strength, in addition to good oxidation resistance, at elevated temperatures. The aluminide is a

Fig. 2. Effect of test environment on fatigue-crack-growth rate $(\mathrm{da} / \mathrm{dN})$ of a $\mathrm{DO}_{3}-\mathrm{Fe}_{3} \mathrm{Al}$ alloy $(\mathrm{FA}-129: \mathrm{Fe}$ $28 \mathrm{Al}-5.0 \mathrm{Cr}-0.5 \mathrm{Nb}-0.2 \mathrm{C}$, at. \%) tested at room temperature [33]. 


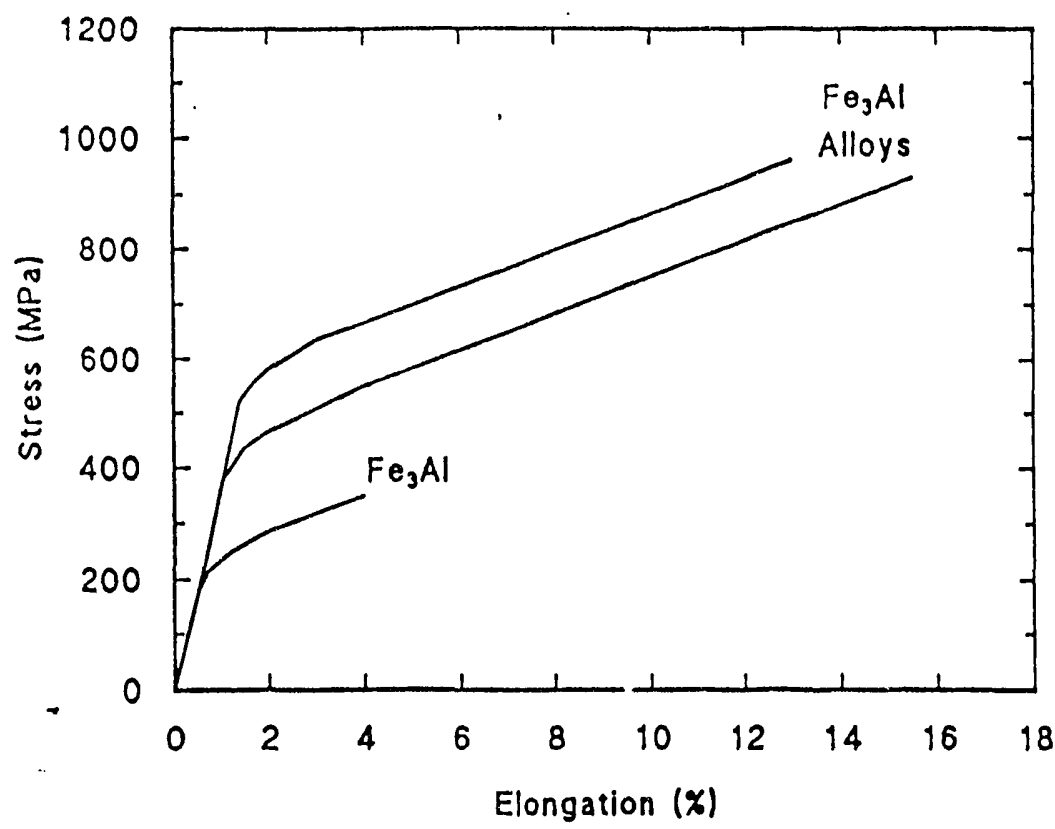

Fig. 3. Comparison of the stress-strain curve of binary $\mathrm{Fe}_{3} \mathrm{Al}\left(28\right.$ at. \% Al) with ductile $\mathrm{Fe}_{3} \mathrm{Al}$ alloys developed by thermomechanical treatment and alloying additions [14]. All specimens were tested at room temperature in air. model material to study the yield anomaly and brittle grainboundary fracture. The detailed mechanism governing the positive temperature dependence of flow strength in $\mathrm{Ni}_{3} \mathrm{Al}$ and other $\mathrm{L}_{2}$ ordered intermetallics is given in the review paper by Hirsch in this proceedings [13]. The previous work on brittle grain-boundary fracture and ductilizing effect of boron was given in the viewpoint set in Scr. Metall., 1991 [37]. This paper will focus on some new evidence in connection with the brittle grain-boundary fracture in $\mathrm{Ni}_{3} \mathrm{Al}$ and other $\mathrm{L}_{2}$ 8 intermetallics discovered in the last couple of years.

The grain boundary in binary $\mathrm{Vi}_{3} \mathrm{Al}$ was considered to be intrinsically brittle mainly because no appreciable impurities at grain boundaries had been detected by Auger analyses [38-40]. In 1991, Liu et al. [41,42] had made a first attempt to link brittle intergranular fracture with environmental embrittlement in binary $\mathrm{Ni}_{3} \mathrm{Si}$ and $\mathrm{Ni}_{3} \mathrm{Al}$. Table 1 shows the tensile properties of recrystallized polycrystalline $\mathrm{Ni} 3 \mathrm{Al}$ alloys produced by repeated cold forging and $1000^{\circ} \mathrm{C}$ annealing. The aluminides containing 23.5 to $24 \% \mathrm{Al}$ showed only 2.5 to $2.6 \%$ elongation in air but 7.2 to $8.2 \%$ in dry oxygen, an increase in ductility by a factor of $\sim 3$. These results clearly demonstrate that binary $\mathrm{Ni} 3 \mathrm{Al}$ alloys are prone to environmental embrittlement at room temperature. Thus, the extrinsic factor-environmental embrittlement-is a major cause of low ductility and brittle intergranular fracture in binary $\mathrm{Ni} 3 \mathrm{Al}$ [41].

The environmental embrittlement is apparently not the sole source of grain-boundary brittleness in $\mathrm{Niz} \mathrm{Al}$, because the elimination of the environmental effect by testing in dry oxygen does not lead to extensive ductility (e.g. $>30 \%$ ) and suppression of intergranular fracture in $\mathrm{Ni} 3 \mathrm{Al}$. Another factor governing the brittle intergranular fracture is the poor grain-boundary cohesion due to high ordering energy and the large difference in electronegativity and valence electron between nickel and aluminum atoms [43-47]. Atomistic simulation calculations suggest that the high ordering energy in $\mathrm{Ni}_{3} \mathrm{Al}$ reduces atomic relaxation in the grain-boundary region and causes a formation of columnar "cavities," which serve as suitable sites for nucleation and growth of intergranular cracks [48-51]. This is illustrated in Fig. 4, where the calculated structure of the $\Sigma=29(520) /\left[001\right.$ ] symmetrical tilt boundaries in weakly ordered $\mathrm{Cu}_{3} \mathrm{Au}$ is compared with that in strongly ordered $\mathrm{Ni}_{3} \mathrm{Al}$. The formation of the cavities is visible along the grain boundary in $\mathrm{Ni} 3 \mathrm{Al}$.

It is difficult to assess the relative importance of the two causes of brittle grain-boundary fracture in Ni3Al. Takasugi et al. [20] first reported the environmental effect on ductility reduction in beryllium-doped $\mathrm{Ni} 3 \mathrm{Al}$, but not in binary $\mathrm{Ni}_{3} \mathrm{Al}(24 \% \mathrm{Al})$. The $\mathrm{Ni} 3 \mathrm{Al}$ alloy doped with 1 at. \% Be showed a tensile ductility of 5\% in vacuum but $1 \%$ in air. On the other hand, no environmental effect was detected in cast binary $\mathrm{Ni}_{3} \mathrm{Al}$, which exhibited very limited plastic deformation at room temperature. Manganese at a level of 15 at. \% was added for enhancement of the grain-boundary cohesion in Ni3Al [53]. Masahashi et al. [53] found that the tensile ductility of $\mathrm{Ni} 3(\mathrm{Al}, \mathrm{Mn})$ is highly susceptible to environmental embrittlement at room temperature at different strain rates. Note that the environment effect was thought previously to be associated with the ternary alloying additions added to $\mathrm{Ni}_{3} \mathrm{Al}$ (rather than in connection with binary $\mathrm{Ni} 3 \mathrm{Al}$ ) until the recent finding of a clear environmental effect in fabricated and recrystallized $\mathrm{Ni}_{3} \mathrm{Al}$ and $\mathrm{Ni}_{3} \mathrm{Si}[41,42]$. 
Table I. Effect of test environment on room-temperature tensile properties of binary $\mathrm{Ni}_{3} \mathrm{Al}$ $(\mathrm{Ni}-23.5 \% \mathrm{Al})$ and $\mathrm{Zr}$-doped $\mathrm{Ni} 3 \mathrm{Al}(\mathrm{Ni}-22.65 \%-0.26 \% \mathrm{Zr})$

\begin{tabular}{|c|c|c|c|}
\hline Test environment & $\begin{array}{l}\text { Tensile ductility } \\
(\%)\end{array}$ & $\begin{array}{l}\text { Yield strength } \\
(\mathrm{MPa})\end{array}$ & $\begin{array}{l}\text { Ultimate tensile } \\
\text { strength } \\
(\mathrm{MPa})\end{array}$ \\
\hline
\end{tabular}

$\mathrm{Ni-23.5 \%}$ Al [41]

$\begin{array}{cccc}\text { Air } & 2.5 & 193 & 230 \\ \text { Oxygen } & 8.2 & 194 & 351\end{array}$

$\mathrm{Ni}-22.65 \% \quad \mathrm{Al}-0.26 \% \mathrm{Zr}[54]$

\begin{tabular}{crrr} 
Water & 8.7 & 322 & 528 \\
Air & 13.2 & 324 & 661 \\
Oxygen & 50.6 & 326 & 1451 \\
\hline
\end{tabular}

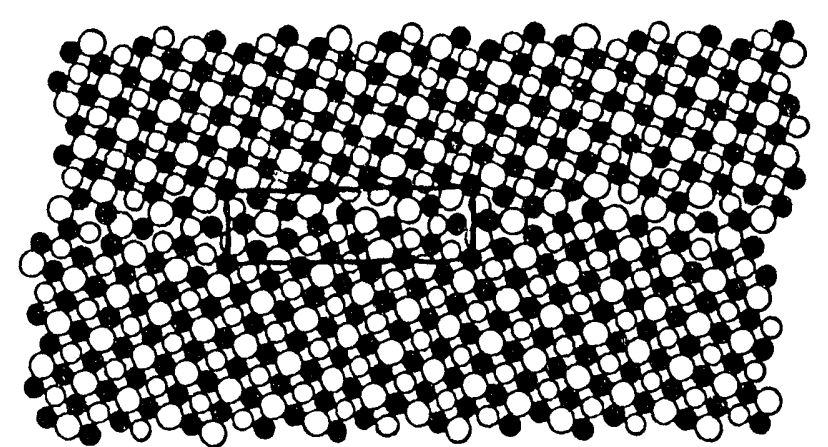

(a)

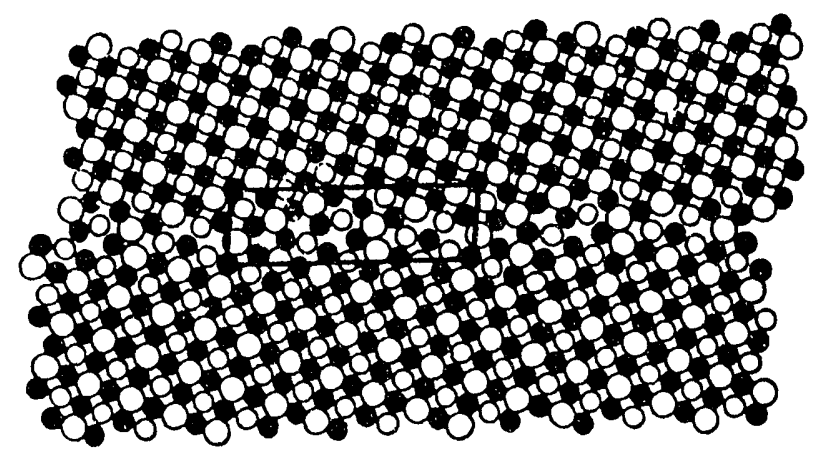

(b)

Fig. 4. Calculated structures of the $\Sigma=29(520) /[001]$ symmetrical tilt boundaries in: (a) $\mathrm{Cu}_{3} \mathrm{Au}$ and (b) $\mathrm{Ni}_{3} \mathrm{Al}$ projected onto the (001) plane. In these figures atoms are depicted as shaded circles of two different sizes. The larger circles correspond to Au or $\mathrm{Al}$ and smaller circles to $\mathrm{Cu}$ or $\mathrm{Ni}$, respectively. The shading distinguishes two different (002) layers in the [001] period [50].

More recently, George et al. [54] have studied the environmental effect in a carefully prepared $\mathrm{Ni} 3 \mathrm{Al}$ alloy with the composition of $\mathrm{Ni}-22.65 \% \mathrm{Al}-0.26 \% \mathrm{Zr}$, where zirconium was added to enhance the grain-boundary properties. In this case, the polycrystalline material was prepared from recrystallization of cold-worked single crystals. As shown in Table 1, the polycrystalline specimens exhibited a room-temperature tensile ductility of 8.7 in water, $13.2 \%$ in air, and $50.6 \%$ in oxygen. These results demonstrate that, by adding zirconium to eliminate the intrinsic source of grain-boundary brittleness, the $\mathrm{Ni} 3 \mathrm{Al}$ alloy becomes very sensitive to test environment. The ductility increases from 8.7 to $50.6 \%$ by testing the alloy in a dry environment. Moisture-induced hydrogen environment has been observed in many other $\mathrm{L}_{2}$ intermetallics, including $\mathrm{Ni}_{3} \mathrm{Si}$ [42], $\mathrm{Ni}_{3}(\mathrm{Si}, \mathrm{Ti})$ [55], $\mathrm{Co}_{3} \mathrm{Ti}$ [52], and (Fe, $\left.\mathrm{Co}\right)_{3} \mathrm{~V}$ [56,57] alloys.

Boron has been found to be most effective in improving the tensile ductility of $\mathrm{Ni}_{3} \mathrm{Al}$ $(<25 \% \mathrm{Al})$ tested in air at room temperature $[38,58]$. In view of the recent finding of environmental embrittlement, the ductilizing effect of boron was reassessed by testing borondoped $\mathrm{Ni} 3 \mathrm{Al}(24 \% \mathrm{Al})$ in various environments. As shown in Table 2 [59], all specimens, including the one tested in water, are ductile with tensile elongation more than $35 \%$ and fracture in a transgranular mode. These results indicate sat boron-doped $\mathrm{Ni}_{3} \mathrm{Al}$ is not sensitive to test environment at room temperature, consistent with the early data reported by Takasugi et al. [20]. Thus, boron is effective in eliminating environmental embrittlement in Ni3 Al. Since boron and hydrogen both occupy interstitial sites, it is reasonable to assume that the strong segregation of 
Table II. Effect of test environment on room-temperature tensile properties of B-doped $\mathrm{Ni} 3 \mathrm{Al}(24 \% \mathrm{Al})$ [59]

\begin{tabular}{lccc}
\hline $\begin{array}{c}\text { Test } \\
\text { environment }\end{array}$ & $\begin{array}{c}\text { Elongation } \\
(\%)\end{array}$ & \multicolumn{2}{c}{ Strength $(\mathrm{MPa})$} \\
\cline { 2 - 3 } & & & Yield \\
\hline Oxygen & 42.8 & 289 & 1315 \\
Air & 39.3 & 280 & 1241 \\
Water & 36.8 & 288 & 1120 \\
\hline
\end{tabular}

boron to $\mathrm{Ni} 3 \mathrm{Al}$ grain boundaries would block the diffusion of hydrogen along the boundaries and thus alleviate hydrogen embrittlement. Boron-free Ni3Al (24\% Al) showed a ductility of only $7.2 \%$ in dry oxygen while boron-doped $\mathrm{Ni}_{3} \mathrm{Al}$ exhibited $50.6 \%$. This comparison suggests that boron segregation also enhances the grain-boundary cohesion in $\mathrm{Ni} 3 \mathrm{Al}$.

The NizAl phase is capable of dissolving substantial alloying additions that strongly affect the mechanical and metallurgical properties of Ni3Al. Recent alloy design efforts have led to the development of $\mathrm{Ni} 3 \mathrm{Al}$-base alloys with the following composition range for structural use at elevated temperatures in hostile environments [60-62]:

$$
\mathrm{Ni}-14 \text { to } 18 \mathrm{Al}-6 \text { to } 9 \mathrm{Cr}-1 \text { to } 4 \mathrm{Mo}-0.01 \text { to } 1.5 \mathrm{Zr} / \mathrm{Hf}-0.01 \text { to } 0.20 \mathrm{~B} \text { (at. \%) }
$$

Ir $_{i}$ :hese aluminide alloys, chromium at a level of 6 to $9 \%$ is added for reducing environmental embrittlement in oxidizing environments at elevated temperatures. Zirconium and hafnium additions are most effective in improving the high-temperature strength via solid-solution hardening effects. Molybdenum additions are added for improving strength at ambient and elevated temperatures. Microalloying with boron reduces moisture-induced hydrogen embrittlement and enhances grain-boundary cohesive strength, resulting in sharply increased ductility at ambient temperatures. In some cases, moderate amounts $(<20 \%)$ of cobalt and iron are added to replace $\mathrm{Ni}$, and $\mathrm{Al}$ and $\mathrm{Ni}$, respectively, in order to further improve hardness and corrosion resistance $[63,64]$. The alloys with optimum properties usually contain 5 to 15 vol \% of the disordered $\gamma$ phase, which has the beneficial effect of reducing environmental embrittlement in oxidizing atmospheres and improving creep properties at elevated temperatures.

Cast aluminide alloys usually possess a coarse grain structure which lowers the yield strength at anbient temperatures. The strength can be effectively increased by alloying with molybdenum via solid-solution hardening. The aluminide alloys prepared by investment casting possess good mechanical properties. The strength of a cast Ni3Al alloy (IC-221M: Ni-15.9Al$8.0 \mathrm{Cr}-0.8 \mathrm{Mo}-1.0 \mathrm{Zr}-0.03 \mathrm{~B}$, at. \%) is comparable to the superalloy IN-713C at room temperature but is much higher at higher temperatures $\left(e . g ., 1000^{\circ} \mathrm{C}\right)$. The high-cycle fatigue life of IC-221M is longer than that of IN $-713 \mathrm{C}$ by more than two orders of magnitude at $650^{\circ} \mathrm{C}$ in air [65]. The cast aluminide alloys usually have a tensile elongation of 10 to $30 \%$ at room and elevated temperatures.

Limited effort has been devoted to the development of single crystals and directionally solidified Ni3Al alloys. Han et al. [66] have recently developed a strong NizAl-base alloy prepared by directional solidification (DS). The alloy (density $=7.91 \mathrm{~g} / \mathrm{cm}^{3}$ ) has a simple composition of $\mathrm{Ni}-16.3 \mathrm{Al}-8.2 \mathrm{Mo}-0.2 \mathrm{~B}$ (at. \%), with molybdenum as the major solid-solution strengthener. It has a yield strength of $990 \mathrm{MPa}$ at $700^{\circ} \mathrm{C}, 600 \mathrm{MPa}$ at $1000^{\circ} \mathrm{C}$, and $520 \mathrm{MPa}$ at $1050^{\circ} \mathrm{C}$, all of which appear to be higher than those of existing nickel-base superalloys in singlecrystal or DS forms. Table 3 shows that the Ni3Al alloy is better than PWA 1422 in creep resistance at high temperatures, particularly above $1000^{\circ} \mathrm{C}$. The excellent mechanical properties of the Ni3Al alloy are attributed mainly to solid-solution hardening by molybdenum and secondphase strengthening by 15 to $20 \% \gamma$ phase (with a lattice misfit of $1.24 \%$ between $\gamma$ and $\gamma$ phases). This result has demonstrated the possibility of the development of promising NizAlbase alloys for structural applications above $1000^{\circ} \mathrm{C}$. Additional development work is certainly needed for further optimizing the alloy composition and properties. 
Table III. Comparison of creep properties of an advanced DS Ni3Al alloy (Ni-16.3Al-8.24Mo$0.26 \mathrm{~B}$, at. \%) with a strong commercial alloy PWA 1422 (Ni-11.23Al-11.89Cr-4.93Co-3.95Ta$1.76 \mathrm{Ti}-1.29 \mathrm{~W}$, at. \%) (data from [66])

\begin{tabular}{cccr}
\hline \multicolumn{2}{c}{ Creep condition } & \multicolumn{2}{c}{ Rupture life (h) } \\
\cline { 4 - 4 } $\begin{array}{c}\text { Temperature } \\
\left({ }^{\circ} \mathrm{C}\right)\end{array}$ & $\begin{array}{c}\text { Stress } \\
(\mathrm{MPa})\end{array}$ & Ni3Al alloy & PWA 1422 \\
\hline & 765 & & \\
760 & 137 & 190 & 100 \\
1040 & 88 & 254 & 100 \\
1100 & & & 43 \\
\hline
\end{tabular}

\section{NiAI AND MINOR ALLOY ADDITIONS}

Nickel aluminide containing more than about 41 at. \% Al starts to form a single-phase ordered B2 structure based on the body-centered cubic (bcc) lattice. In terms of thermophysical properties, $\mathrm{B} 2 \mathrm{NiAl}$ offers more potential for high-temperature applications than $\mathrm{L}_{2} \mathrm{Ni}_{3} \mathrm{Al}$ $[67-70]$. It has a higher melting point $\left(1638^{\circ} \mathrm{C}\right)$, a substantially lower density $\left(5.86 \mathrm{~g} / \mathrm{cm}^{2}\right)$, a higher Young's modulus ( $294 \mathrm{GPa})$, and a distinctly higher thermal conductivity $(76 \mathrm{~W} / \mathrm{m}-\mathrm{K})$ at ambient temperatures. In addition, $\mathrm{NiAl}$ has excellent oxidation resistance at high temperatures. In the 1950s and 1960s, NiAl alloys were employed as coating material for hot components in corrosive environments. The oxidation resistance of $\mathrm{NiAl}$ can be further improved by alloying with yttrium and other refractory elements such as zirconium and hafnium [71,72].

The structural use of NiAl suffers from two major drawbacks: poor fracture resistance at ambient temperatures and low strength and creep resistance at elevated temperatures. Single crystals of $\mathrm{NiAl}$ are quite ductile in compression, but both single-crystal and polycrystalline $\mathrm{NiAl}$ appear to be brittle in tension at ambient temperatures. The nickel aluminide exhibits mainly $<100>$ slip, rather than $<111>$ slip as commonly observed for bcc materials [73-75]. The insufficient deformation modes, poor cleavage resistance, and brittle grain-boundary fracture [76] are all considered to be the major causes of low tensile ductility in NiAl. The aluminide shows a sharp increase in ductility above $400^{\circ} \mathrm{C}$ and becomes very ductile above $500^{\circ} \mathrm{C}$ at conventional strain rates $[77,78]$. In general, hot fabrication of $\mathrm{NiAl}$ at elevated temperatures presents no major problems. The brittle grain-boundary fracture in polycrystalline $\mathrm{NiAl}$ can be readily suppressed by microalloying with boron; however, the suppression of intergranular fracture does not lead to increase in ductility as found by George and Liu recently [76].

Because of the excellent high-temperature capability of NiAl, considerable effort has been devoted to understanding brittle fracture and improving mechanical properties of NiAl during the past years. A striking result was reported recently by Darolia et al. $[69,79]$, who observed that the tensile ductility of $\langle 110\rangle$ single-crystal NiAl can be substantially increased by alloying with less than $1 \%$ of alloying additions. As shown in Fig. 5, the room-temperature tensile ductility of $<110>\mathrm{NiAl}$ (a soft orientation) is increased from $1 \%$ to as high as $6 \%$ by adding about 0.2 at. \% Fe. The ductility decreases sharply when the iron content is more than $0.4 \%$. A similar effect, but smaller in scale, is observed for molybdenum and gallium. The ductilizing effect of iron and molybdenum is not detected in polycrystalline NiAl [80], possibly because of strain incompatibility at grain boundaries in association with the deformation of NiAl polycrystals. However, molybdenum-modified $\mathrm{NiAl}$ with a wrought microstructure showed a roomtemperature ductility higher than that of unalloyed $\mathrm{NiAl}$ [80].

Hack, Brzeski, and Darolia [81] have recently reported some interesting results that contribute to our basic understanding of deformation and fracture in single-crystal NiAl. Their study indicates that the fracture resistance of $\langle 110\rangle$ crystals can be dramatically improved by controlled heat treatments. The NiAl crystals furnace-cooled from a homogenization treatment at $1300^{\circ} \mathrm{C}$ exhibited a tensile elongation of $1 \%$ and a fracture toughness of $2.4 \mathrm{MPa} \mathrm{m} 1 / 2$ at room temperature. Surprisingly, the room-temperature ductility increased to $7 \%$ and the toughness went up to $16.7 \mathrm{MPa} \mathrm{m}$ l/2 when NiAl crystals were reheated to $400^{\circ} \mathrm{C}$ followed by air cooling. The beneficial effect of the $400^{\circ} \mathrm{C}$ heat treatrient disappeared as the specimens were cooled down slowly inside a furnace. Hack et al. [81] attribute the low ductility and poor toughness of 


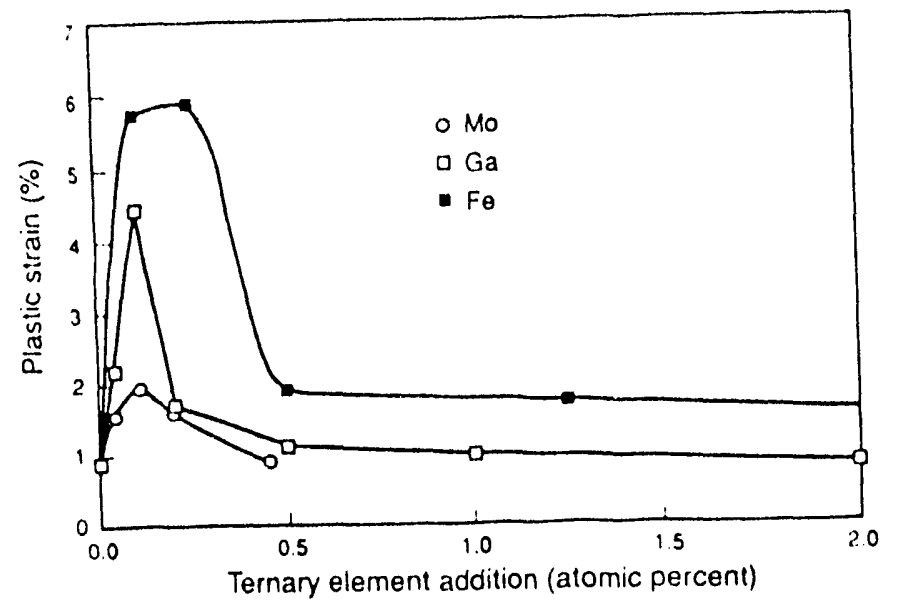

single-crystal NiAl to strain-age embrittlement involving pinning of mobile dislocation by interstitials such as carbon and oxygen, similar to strain-aging embrittlement in high-strength steels [82]. The interstitial content in these NiAl crystals is reported to be only about 100 wt ppm carbon and 50 wt ppm oxygen. The implication of this study is very significant; that is, $\mathrm{NiAl}$ single crystals basically possess reasonable intrinsic ductility and

Fig. 5. Significant improvement in room-temperature tensile ductility of $<110\rangle \mathrm{NiAl}$ by alloying with iron, gallium and molybdenum [69].

toughness at room temperature, and their poor fracture resistance is mainly caused by an extrinsic effect-strain-aging embrittlement by interstitial impurities [82]. Based on this embrittling mechanism, it is expected that the fracture resistance of NiAl crystals can be effectively improved by either reducing the interstitial content or scavenging interstitials by certain alloying additions. Certainly, further research should be directed to this area.

Because of strong affinity between nickel and aluminum atoms, $\mathrm{NiAl}$ can dissolve only limited amounts of solutes, with a solubility limit typically less than a couple of percents. A number of investigators have found that $\mathrm{NiAl}$ in single-crystal or polycrystal forms can be effectively hardened by adding $<1 \%$ solutes. Recently, Noebe, Bowman, and Nathal [70] have compiled the solute-solution hardening data, which are shown as a function of solute radii in Fig. 6. The interstitial elements [76] bcron and carbon and the substitutional elements $[70,83]$ yttrium, zirconium, molybdenum, and lanthanum all have a hardening rate $\left(\Delta \sigma_{y} / \Delta c\right)>1500 \mathrm{MPa}$ per solute atom percent. For instance, alloying with $1 \% \mathrm{Zr}$ increases the yield strength $\left(\sigma_{y}\right)$ of $\mathrm{NiAl}$ by $400 \mathrm{MPa}(58 \mathrm{ksi})$. Note that, because of the extremely low solubility limit of certain elements, the hardening effect detected in many $\mathrm{NiAl}$ alloys actually comes from precipitation of fine second-phase particles, as shown by atom-probe imaging [84] and other microstructural analysis $[70,80,83]$.

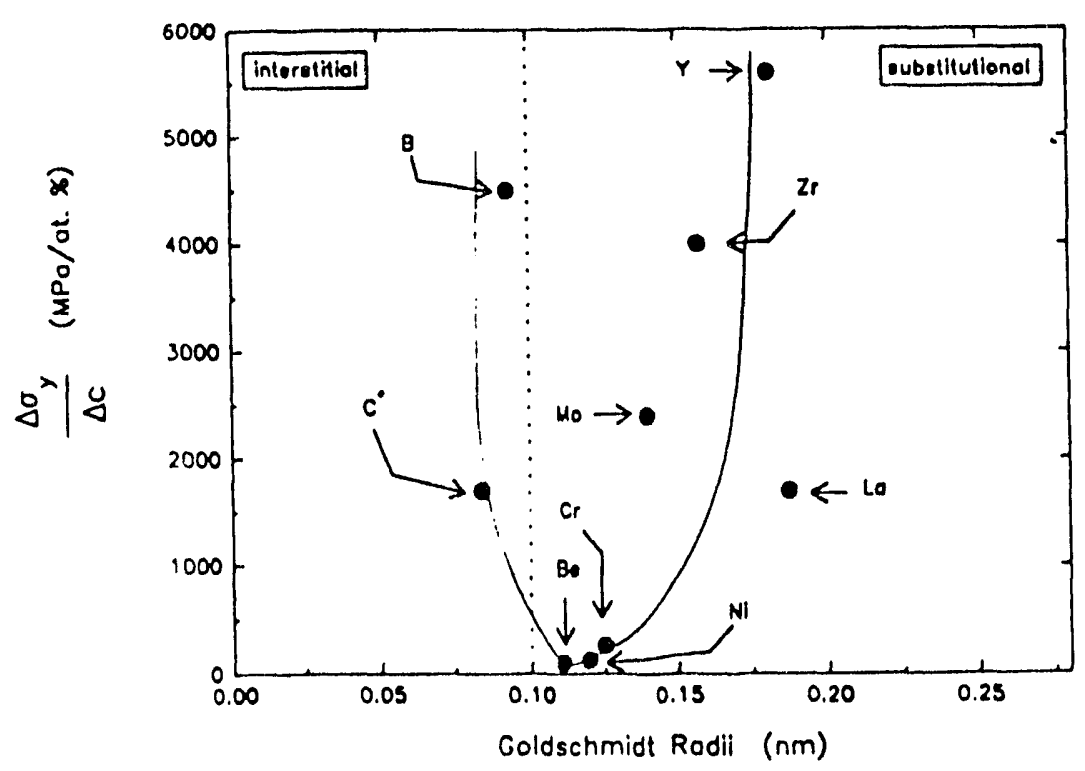

At present, there appears to be no major difficulty in achieving high strength and creep resistance in $\mathrm{NiAl}$ alloys by controlling crystal orientation and alloying additions $[80,85]$. The remaining problem for structural use of NiAl alloys is their poor impact resistance at ambient and elevated temperatures. $\mathrm{NiAl}$ alloys typically show a fracture toughness of 4 to $6 \mathrm{MPa} \mathrm{m}{ }^{1 / 2}$ at room temperature $[70,81,86]$. They generally have extensive tensile ductilities above $600^{\circ} \mathrm{C}$ at conventional strain rates; however, their impact resistance remains poor at elevated temperatures. The poor fracture

Fig. 6. The relationship between hardening rate and atom size for various alloying elements in $\mathrm{NiAl}$ [70]. 
resistance is possibly related to the fact that all thermally activated deformation processes operating at elevated temperatures are suppressed by high strain-rate deformation $[70,87,88]$, such as impact testing.

\section{$\gamma$ TITANIUM ALUMINIDES AND MICROSTRUCTURAL CONTROL}

Titanium aluminides based on $\mathrm{D}_{22}$-TiAl3,$\gamma-\mathrm{TiAl}$, and $\alpha_{2}$-Ti3Al possess some unique properties for structural applications, particularly for aerospace and aeronautic industries $[9,11,89]$. This is due to their sufficiently low material density and high retention of strength and creep resistance at elevated temperatures. $\mathrm{TiAl}_{3}$-base trialuminide alloys with the $\mathrm{Ll}_{2}$ crystal structure are of current interest; however, these alloys remain brittle in tension at ambient temperatures $[90,91]$. The poor fracture resistance simply keeps these alloys outside the realm of engineering materials, and there is no indication of breakthroughs in this area at present. Ti3Albase alloys (such as Ti-24Al-11 Nb and Ti-24Al-10N hand, suffer mainly from structural instability and cracking problems when exposed to hostile environments under cyclic loads $[9,92,93]$. Currently, most efforts on titanium aluminides have been focused on $\gamma$-TiAl alloys which commonlv contain up to $20 \%$ of the $\alpha_{2}$-Ti3Al phase. The $\gamma$-base alloys are superior to $\alpha_{2}$-base alloys because of their higher elevated-temperature strength, better oxidation resistance, and relatively lower material density.

First-principles total-energy quantum mechanical calculations have been advanced to the stage that they are able to help us in understanding the fundamental deformation behavior, in addition to the prediction of phase stability, of order intermetallics $[8,94]$. Recently, Fu and YoO [95-99] have calculated elastic constants, shear-fault energies, Griffith's cleavage strength, and point defects in TiAl and other intermetallics, using the full-potential linearized augmented planewave (FLAPW) method. Table 4 summarizes the calculated results of elastic constants and shear-fault energies for TiAl. Since no experimental data are reported at the present, the calculated elastic constants are the only set of data available for single-crystal TiAl. The calculated shear and bulk moduli of TiAl agree well with the experimental ones, indicating the accuracy of the calculations. The high shear anisotropy $\left(\mathrm{C}_{44} / \mathrm{C}_{66}\right)$ reflects the formation of strong $\mathrm{p}-\mathrm{d}$ bonds between titanium and aluminum atoms. The twin-boundary energy in TiAl is quite low as compared with other calculated shear-fault energies. This is consistent with the experimental observation of twinning deformation active in TiAl alloys tested at various temperatures [100-102]. Thus, the first-principles calculations are effective in predicting the fundamental mechanical behavior in TiAl as well as other ordered intermetallics.

Table IV. Calculated elastic constants $\left(\mathrm{C}_{\mathrm{ij}}\right)$, bulk modulus $(\mathrm{B})$, shear modulus $(\mathrm{G})$, and shear fault energies for TiAl [99]

\begin{tabular}{|c|c|c|c|c|c|c|c|}
\hline \multicolumn{6}{|c|}{ Elastic constants $\left(10^{11} \mathrm{~N} / \mathrm{m}^{2}\right)$} & \multirow{2}{*}{$\frac{\text { Bulk }\left(10^{11} \mathrm{~N} / \mathrm{m}^{2}\right)}{B}$} & \multirow{2}{*}{$\frac{\text { Shear }\left(10^{11} \mathrm{~N} / \mathrm{m}^{2}\right)}{G}$} \\
\hline $\mathrm{C}_{11}$ & $\mathrm{C}_{12}$ & $\mathrm{C}_{13}$ & $\mathrm{C}_{33}$ & $\mathrm{C}_{44}$ & $\mathrm{C}_{66}$ & & \\
\hline 1.90 & 1.05 & 0.95 & 1.85 & 1.20 & 0.50 & 1.25 & 0.70 \\
\hline
\end{tabular}

Shear fault energies $\left(\mathrm{mJ} / \mathrm{m}^{2}\right)$

\begin{tabular}{ccccc}
\hline $\mathrm{APB}_{(010)}$ & $\mathrm{APB}_{(111)}$ & SISF & SESF & TWIN \\
\hline 430 & 510 & 90 & 80 & 60 \\
\hline
\end{tabular}


Yamaguchi and his associates $[10,100,101,103]$ have conducted a systematic study of the mechanical properties of polysynthetically twinned (PST) TiAl crystals (Ti-49 at. \% Al) produced in an optical-floating zone furnace. The crystals have a two-phase structure containing $\gamma$ (the main phase) and $\alpha_{2}$ (the minor phase) lamellae. The $\gamma$ and $\alpha_{2}$ lamellae have the orientation relationship of (111) $\gamma / /(0001) \alpha_{2}$ and [110] $\gamma / /<1120>\alpha_{2}$, where (111) in the $\gamma$-phase is assigned to be parallel to the lamellar boundaries. Figure 7 shows a plot of the room-temperature yield strength as a function of the angle $\phi$ between the lamellar boundaries and tensile axis [100]. The orientation of two crystal groups (1) and (2) is indicated in the stereographic projection of tensile axis orientations shown in Fig. $\%$. The yield strength depends strongly on the angle $\phi$, but the orientation dependence is not exactly symmetrical with respect to $\phi=45^{\circ}$. The variation of yield strength with $\phi$ can be explained by the two main deformation modes (i.e., the true twinning of the $(111\}<\{112]$ type and slip on $\{111\}<\{110])$, both of which are operational for the hard and easy modes of deformation.

The tensile elongation to fracture is also strongly dependent on the angle $\phi$, as indicated in Fig. 8 [100]. A tensile elongation as large as $20 \%$, which is far larger than other reported values for TiAl-base alloys, has been obtained for the soft orientation with $\phi=31^{\circ}$. Fracture occurs in a brittle manner, independent of the ductility. PST crystals failed mainly along various lamellar toundaries in the $\gamma$-phase, except for the $\phi=0^{\circ}$ crystal where fracture occurs across the lamellar boundaries. It is interesting to note that polycrystalline duplex structures produced from master ingots used for preparation of PST crystals exhibited an average elongation of 1 to $2 \%$, which is in good agreement with the reported room-temperature ductilities for nearly stoichiometric TiAl.

Mechanical properties of TiAl alloys are sensitive to alloy composition and microstructure. A great amount of development work has been focused recently on improving the mechanical properties of TiAl alloys by alloying additions and microstructural control $[9-11,100,102]$. These efforts have led to the development of TiAl-base alloys with the following general compositions (at. \%) for structural uses at elevated temperatures [104]:

$$
\text { Ti-(46-49)Al-(0-3)(Cr, Mn, V) -(0.5-6)(Nb, W, or Mo)-(0-1)(Si, B, N, Ni, etc.) . }
$$

The TiAl alloys with 46 to $49 \% \mathrm{Al}$ commonly contain the $\alpha_{2}$ phase, the amount of which depends on aluminum concentration, heat treatment, and microstructural control. $\mathrm{Cr}, \mathrm{Mn}$, and $\mathrm{V}$ at levels up to $3 \%$ are added to enhance the ductility of TiAl through different proposed mechanisms including promotion of twinning, reduction in the c/a ratio, and lowering of aluminum level in the $\gamma$-phase, etc. Nb, W, and Mo are effective in improving the strength and oxidation resistance of 'TiAl alloys at elevated temperatures. Alloying with up to $1 \%$ of Si, B, N, and $\mathrm{Ni}$ generally enhances alloy castability and refines the grain structure. Silicon additions are also reported to be beneficial for oxidation resistance.

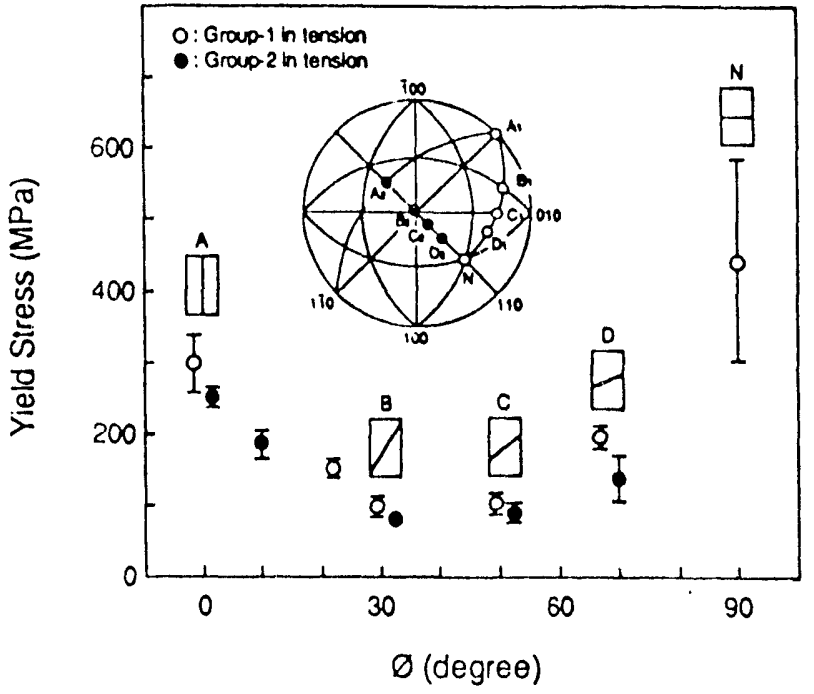

Fig. 7. Plot of the room-temperature yield strength of PST TiAl crystals tested in tension as a function of the angle $\varnothing[100]$.

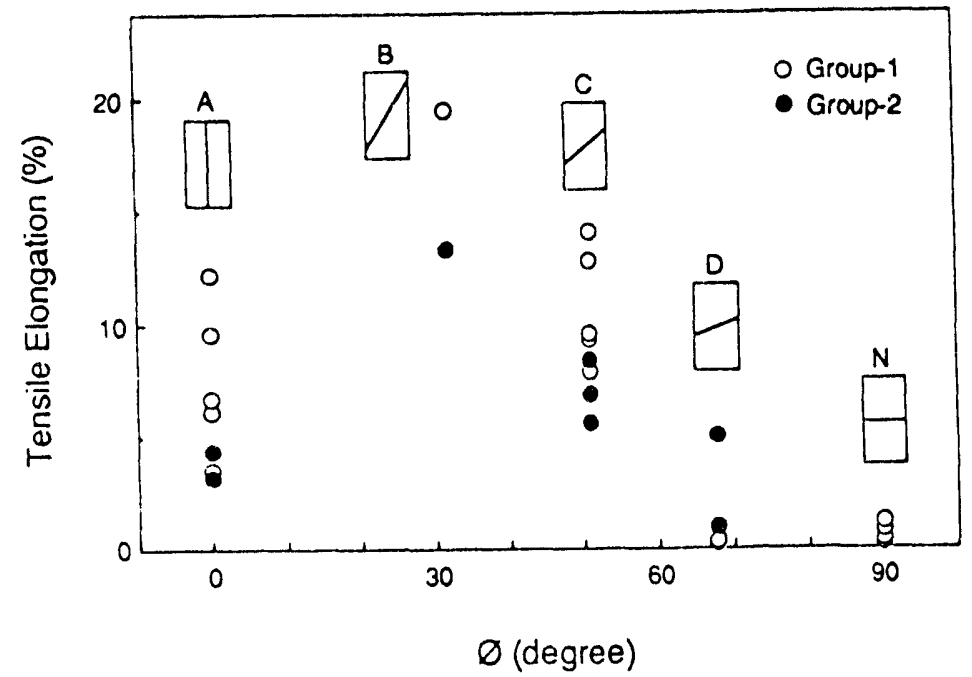

Fig. 8. Plot of the room-temperature tensile elongation of PST TiAl crystals as a function of the angle $\varnothing$ [100]. 
Figure 9 schematically illustrates the relations between microstructure and tensile properties/fracture toughness at room temperature. Microstructures in TiAl alloys are expressed in terms of the relative volume fractions of equiaxed gamma $(G)$, fully lamellar structure $(\mathrm{L})$, and duplex structure of $G$ and $L(G+L)$. The grain size and microstructures can be controlled by thermomechanical treatment, with feature temperatures corresponding to various phase stabilities in the Ti-Al system. The general trend in Fig. 9 indicates that the $\mathrm{G}+\mathrm{L}$ microstructure with a fine grain size gives the best tensile ductility $(\sim 4 \%)$ but lowest fracture toughness $\left(\sim 10 \mathrm{MPa} \mathrm{m}{ }^{1 / 2}\right)$. On the other hand, the fully lamellar (L) structure with a coarse grair size gives almost the highest fracture toughness $\left(-30 \mathrm{MPa} \mathrm{m}^{1 / 2}\right)$ but the lowest tensilc ductility $\left.:<1 \%\right)$. Also, the TiAl alloys with a coarse lamellar structure generally exhibit excellent creep resistance at elevated temperatures.

The inverse relationship between tensile ductility and fracture toughness at room temperature provides a challenge to materials engineers for microstructural design of TiAl alloys. To date, Kim and his associates $[102,104,105]$ have made significant progress in modifying the lamellar structure by innovative thermomechanical treatment or processing. The desired microstructures should be close to nearly fully lamellar structure with a finer grain size. Table 5 compares expected mechanical properties from designed microstructures with duplex and fully lamellar structures $\mathrm{n} \mathrm{TiAl}$ alloys based on the compositions shown in Eq. (4). Limited results generated so far have demonstrated the feasibility of achieving optimum properties from designed microstructures.

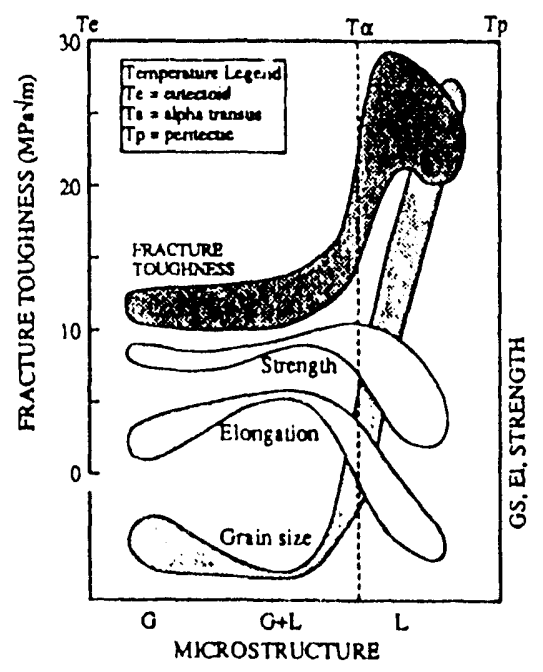

Fig. 9. Schematic relations among microstructure $(\mathrm{G}, \mathrm{G}+\mathrm{L}, \mathrm{L})$, grain size, fracture toughness and tensile properties of TiAl alloys [102].

\section{INDUSTRIAL INTEREST AND POTENTIAL USE OF INTERMETALLIC ALLOYS}

Recent research and development efforts on ordered intermetallics have resulted in substintial improvement in their mechanical and netallurgical properties. The intermetallic alloys with improved properties offer advantages over many conventional materials for structural applications at elevated temperatures in hostile environments. As compared with $\mathrm{Ni}$-base superalloys, Ni3Al alloys developed so far have better fatigue resistance, better oxidation resistance, relatively lower density, and higher

Table V. Effect of microstructure on mechanical properties of TiAl alioys with compositions listed in Eq. (4) [104]

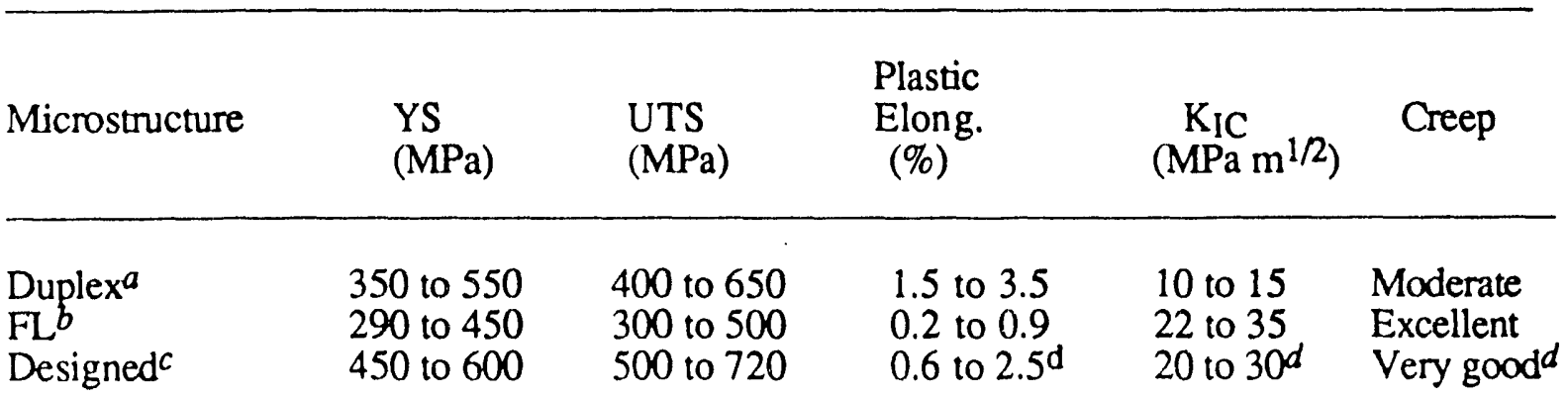

Duplex: A mixture of equiaxed gamma and lamellar structures.

$b$ FL: Fully lamellar structure.

cDesigned: Designed microstructure-nearly lamellar structure with a finer grain size.

${ }^{d}$ Expected values. 
high-temperature strength under high strain-rate deformation [60-62,66]. Iron-aluminide alloys with excellent oxidation and corrosion resistance and low material density and cost are superior to ferritic steels and austenitic stainless steels for many structural applications [14]. NiAl alloys possess better oxidation resistance, lower material density, higher melting point, and better thermal conductivity than nickel-base superalloys [70]. In comparison with titanium-base alloys, $\gamma$ titanium aluminide alloys offer the advantages of lower material density and better elevatedtemperature strength and oxidation resistance $[9,11,102]$.

The unique properties of many intermetaliic alloys have drawn attention recently from industries for structural applications. At present, the successful development of intermetallic alloys is critically dependent on industrial participation in material processing, data base generation. and structural utilization of these alloys as hot components in engineering systems. A brief description of the current industrial interest and potential use of the intermetallic alloys is outlined below:

1. Diesel-engine turbocharger rotors: Cummins Engine Company, PCC Airfoils, and Oak Ridge National Laboratory (ORNL) are jointly pursuing the use of Ni3Al alloys for turbocharger rotors in diesei engine trucks [106]. The aluminide alloy IC-221M (Ni-15.9 Al8.0 Cr-0.8 Mo-1.0 Zr-0.03 B, at. \%) with a good castability has been selected for this - application. Aluminide rotors have been successfully produced by investment casting at PCC (Fig. 10). This castable aluminide alloy is expected to replace $\mathrm{IN}-713 \mathrm{C}$ with the major benefits of improved fatigue life and potential for lower cost.

2. Higl-temperature dies and molds: The good high-temperature oxidation resistance, together with excellent strength at high strain rates, makes $\mathrm{Ni3Al}$ alloys attractive as die material for isothermal forging and mold material for glass processing. At present, Ni3Al alloys are being evaluated for these applications in several companies [106].

3. Furnace fixtures for heat treating auto parts: Because of its resistance to carburizing and oxidizing atmospheres, the Ni3Al alloy IC-221M is currently being evaluated by General Motors (Saginaw Division) and ORNL for use as a fixture material for heat treatment of auto parts in high-temperature furnaces. The Saginaw Division has the world's largest heattreatment facility with a heat-treatment capability of about 6000 tons per day. The HU alloy (Fe-40 Ni-20 Cr-2.5 Si-2.0 Mn-0.5 Mo-0.4 C, wi \%) is currently used for furnace fixtures, which cracked badly after $\sim 500$ thermal cycles. Ni3Al alloy furnace fixtures have been successfully made by sand casting, and the evaluation of their performance is in progress [107].

4. Rollers for steel slab heating furnaces: The high-temperature strength, together with good oxidation and corrosion resistance of $\mathrm{Ni3} \mathrm{Al}$ alloys, can produce significant savings in energy costs by not requiring water cooling and in material costs by extending the life four to six times over the current material in use [106].

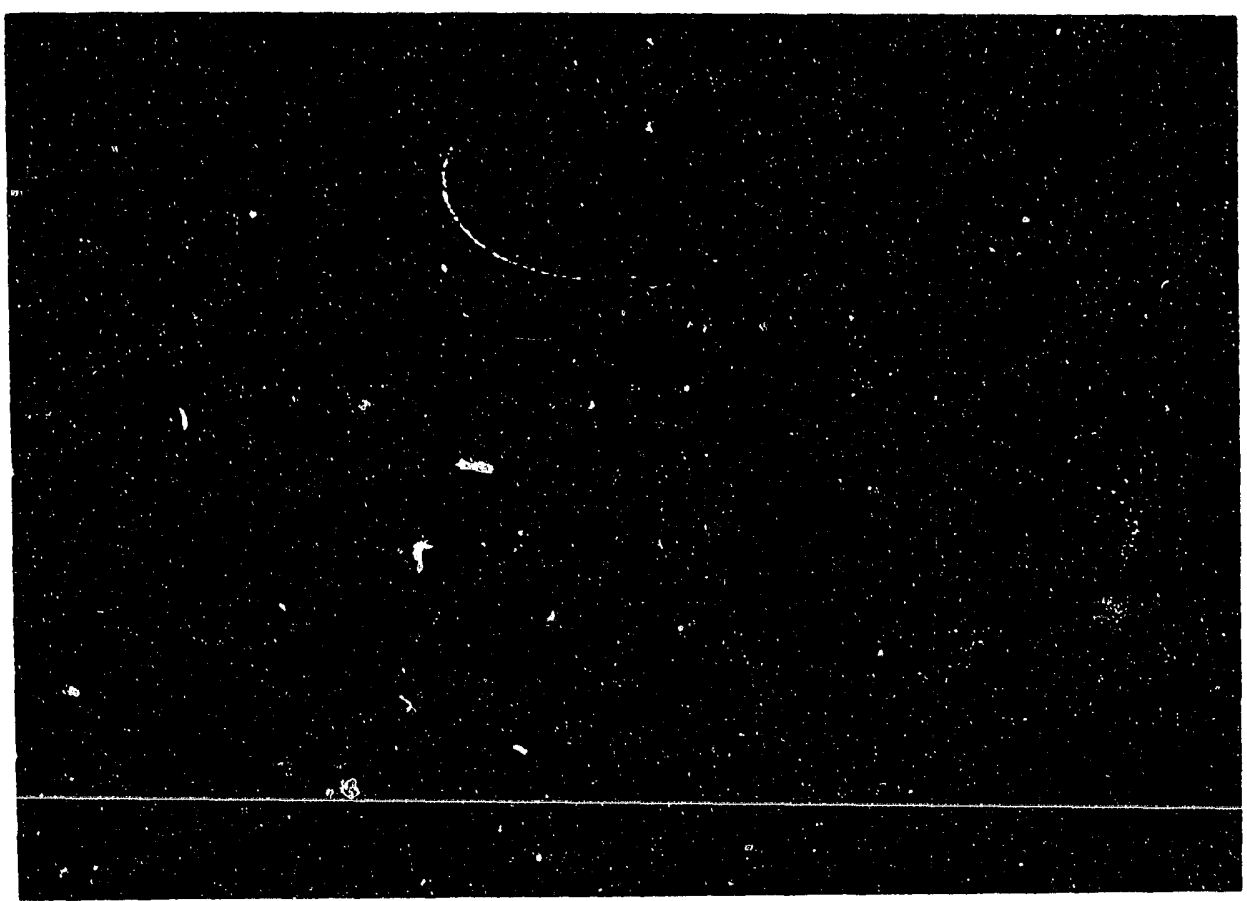

Fig. 10. $\mathrm{Ni}_{3} \mathrm{Al}$-alloy turbocharger rotor made by investment casting [106]. 
5. Turbine blades for jet-engine applications: General Electric has a major effort on developing single-crystal $\mathrm{NiAl}$ alloy turbine blades for new-generation jet-engine applications $[69,85,108]$. The NiAl-base alloys are selected because of their good high-temperature capability, low material density, high stiffness, and excellent thermal conductivity. Figure 11 shows a high-pressure turbine blade machined from a single-crystal NiAl alloy ingot. The $\mathrm{NiAl}$ alloys developed so far have adequate high-temperature strength and creep resistance, and further improvement in fracture toughness and impact resistance at ambient and elevated temperatures is being pursued.

6. Lightweight auto parts: Toyota Motor Corporation has reported a dramatic reduction in grain size of cast TiAl alloy ingots by additions of $\geq 0.3 \mathrm{wt} \% \mathrm{~N}$ [109]. Toyota is now developing lightweight auto parts using grain-refined TiAl alloys.

7. Vanes, blades, and turbocharger rotors for engine applications: Several companies including Ishikawajima-Harima Heavy Industries (IHI) are currently developing and processing TiAlbase alloys for engine applications [109]. Various engine parts made from TiAl alloys are successfully fabricated by innovative casting methods. Figure 12 shows various turbocharger rotors, turbine blades, and vanes made from TiAl alloys containing $\mathrm{Fe}, \mathrm{V}$, and $B$ and fabricated at IHI. The beneficial effects of these elements are mentioned in the paragraph describing the TiAl alloy compositions [see Eq. (4)].

\section{BRIEF SUMMARY AND REMARKS}

At present, there is world-wide interest in research and development of ordered intermetallic alloys for structural use at elevated temperatures in hostile environments. As a result, a great deal of knowledge has been gained in understanding physical metallurgy and mechanical behavior of intermetallic alloys based on nickel, iron, and titanium aluminides. The alloy design efforts have led to the development of useful intermetallic alloys based on $\mathrm{Ni}_{3} \mathrm{Al}, \mathrm{NiAl}, \mathrm{Fe}_{3} \mathrm{Al}, \mathrm{FeAl}, \mathrm{Ti}_{3} \mathrm{Al}$, and $\mathrm{TiAl}$ systems for structural applications. Industrial interest in these intermetallic alloys with improved mechanical and metallurgical properties is high, and several examples of industrial involvement in processing and utilization of these intermetallic alloys are mentioned. Currently, the knowledge and experience gained from the aluminide development have been extended to silicides and other intermetallic systems, including disilicides (e.g., MoSi2) [110,111], A 15 compounds (e.g., Nb3 Al) [112,113], Laves-phase (e.g., Cr2 Nb) [114,115] alloys, etc.

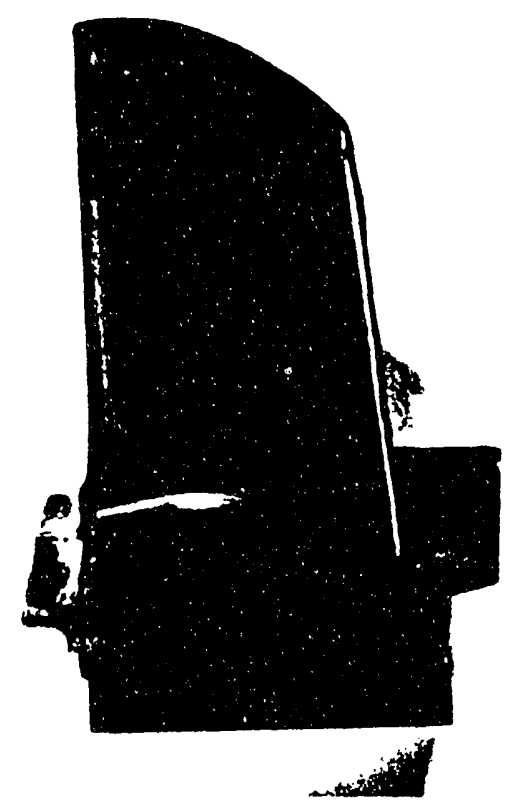

Ordered intermetallics have been employed or have the potential to be used in many other areas besides structural applications [11]. Molybdenum disilicide has been used commercially as electrical heating elements in high-temperature furnaces since 1956 [116]. NiTi alloys, referred to as Nitinol [117-119], are currently the major shape-memory material for systems control in the building, automobile, and automation industries. Considerable efforts are now being devoted to the development of new shape-memory alloys based on intermetallics (e.g., $\mathrm{NiAl} / \mathrm{Ni} 3 \mathrm{Al}$ ) for use at temperatures above ambient $\left(>100^{\circ} \mathrm{C}\right)$ [120]. Many ordered intermetallics possess special attractive properties for magnetic, optical, and electronic applications. A prominent example is the use of $\mathrm{NdFe}_{14} \mathrm{~B}_{2}$ as ahardmagnetic material for high-energy applications

Fig. 11. A high-pressure turbine blade machined from a single-crystal NiAl ingot [108]. 

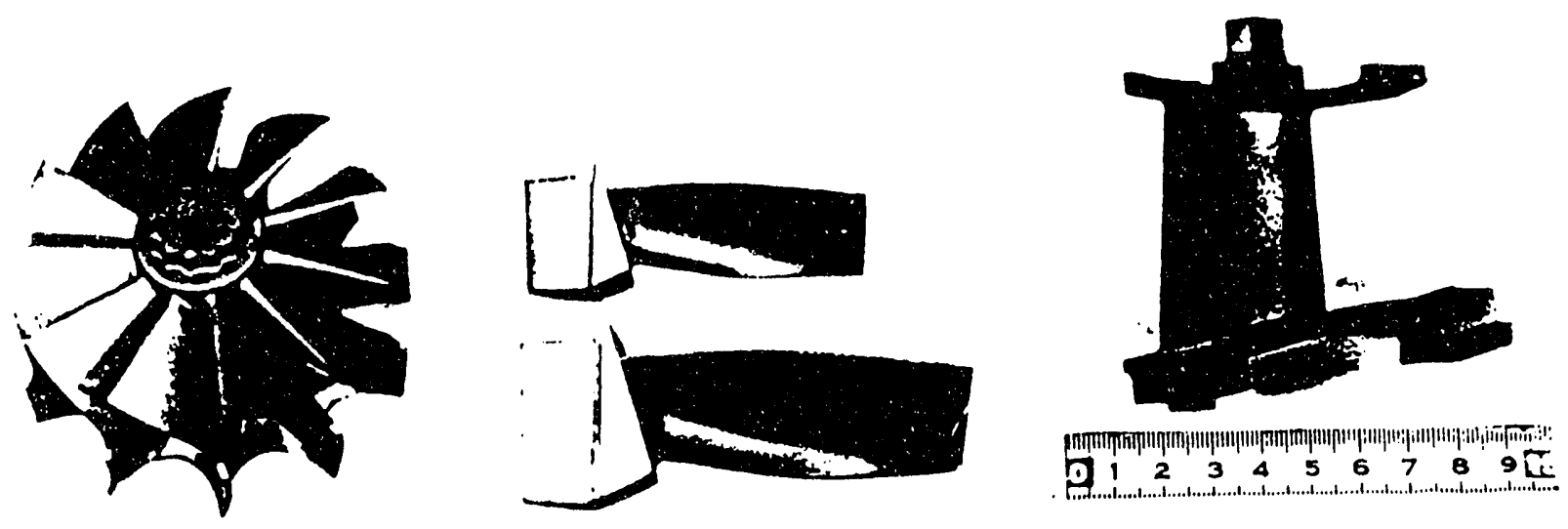

Fig. 12. Cast turbocharger rotor, turbine blade and turbine vane made from TiAl alloys (doped with Fe, V, B) and fabricated at IHI [109].

$[121,122]$. Epitaxially grown $\mathrm{CoSi}_{2}$ and $\mathrm{NiSi}_{2}$ are used in novel devices like the metal base transistors and the permeable base transistors [123]. A-15 compounds such as $\mathrm{Nb}_{3} \mathrm{Sn}$ and $\mathrm{Nb}_{3} \mathrm{Al}$ are attractive as superconducting materials for industrial applications. It is our hope that the knowledge and experience gained from the development of structural intermetallic alloys will be applied to improve the performance of non-structural intermetallic materials in the coming years.

\section{ACKNOWLEDGMENTS}

The author is grateful to Drs. M. Yamaguchi, Y-W. Kim, R. Darolia, M. H. Yoo, C. L. $\mathrm{Fu}$, and K. S. Kumar for unpublished materials and valuable discussions. Thanks are due to E. P. George and J. H. Schneibel for reviewing the manuscript and Millie Atchley, Patty Boyd, and Connie Dowker for manuscript preparation. The author also thanks K. Spence for editing. This research was sponsored by the Division of Materials Sciences, Assistant Secretary for Conservation and Renewable Energy/Office of Industrial Technologies/Advanced Industrial Concepts (AIC) Materials Program, and Fossil Energy AR\&TD Materials Program, U.S. Department of Energy under contract DE-AC05-84OR21400 with Martin Marietta Energy Systems, Inc.

\section{REFERENCES}

1. C. C. Koch, C. T. Liu, and N. S. Stoloff, ed. "High Temperature Ordered Intermetallic Alloys," in Proceedings of Materials Research Society Symposium (Mater. Res. Soc. Proc. 39, Pittsburgh, PA, 1985).

2. N. S. Stoloff, C. C. Koch, C. T. Liu, and O. Izumi, ed. "High Temperature Ordered Intermetallic Alloys II," in Proceedings of Materials Research Society Symposium (Mater. Res. Soc. Proc. 81, Pittsburgh, PA, 1987).

3. C. T. Liu, A. I. Taub, N. S. Stoloff, and C. C. Koch, ed. "High Temperature Ordered Intermetallic Alloys III," in Proceedings of Materials Research Society Symposium (Mater. Res. Soc. Proc. 133, Pittsburgh, PA, 1989).

4. L. A. Johnson, D. P. Pope, and J. O. Stiegler, ed. "High Temperature Ordered Intermetallic Alloys IV," in Proceedings of Materials Research Society Symposium (Mater. Res. Soc. Proc. 213, Pittsburgh, PA, 1991).

5. S. H. Whang, C. T. Liu, D. P. Pope, and J. O. Stiegler, ed. "High Temperature Aluminides and Intermetallics," in Proceedings of TMS/ASM Symposium (TMS-AIME, Warrendale, PA, 1990).

6. S. H. Whang, C. T. Liu, D. P. Pope, and J. O. Stiegler, ed. "High-Temperature Aluminides Intermetallics," Mater. Sci. Eng. A152/A153 (1992).

7. O. Izumi, ed. "Intermetallic Compounds - Structure and Mechanical Properties," in Proceedings of JIMIS-6 (Japan Institute of Metals, Tokyo, 1991). 
8. C. T. Liu, R. W. Cahn, and G. Sauthoff, ed. "Ordered Intermetallics - Physical Metallurgy and Mechanical Behavior," NATO ASI Series, Vol. 213 (Kluwer Academic Publishers, Boston, MA, 1992).

9. Y.W. Kim and R. R. Boyer, ed. "Microstructure/Properties Relationships in Titanium Aluminides and Ailoys" (TMS-AIME, Warrendale, PA, 1991).

10. M. Yamaguchi and Y. Umaknshi, "The Deformation Behavior of Intermetallic Superlattice Compounds," Prog. Mater. Sci. 34(1), 1 (1990).

11. C. T. Liu, J. O. Stiegler, and F. H. Froes, "Ordered Intermetallics," in Metals Handbook, 10th ed., Vol. 2 (ASM, Materials Park, OH, 1990), pp. 913-42.

12. N. S. Stoloff, Int. Met. Rev. 29(3), 123 (1984).

13. I. Baker, R. Darolia, J. D. Whittenberger, and M. H. Yoo, ed. "High Temperature Ordered Intermetallic Alloys $\mathrm{V}, "$ in Proceedings of Materials Research Society Symposium (Mater. Res. Soc. Proc., Pittsburgh, PA, 1993).

14. C. G. McKamey, J. H. DeVan, P. F. Tortorelli, and V. K. Sikka, J. Mater. Res. 6, 1779 (1991).

15. C. T. Liu, E. H. Lee, and C. G. McKamey, Scr. Metall. 23, 875 (1989).

16. C. T. Liu, C. G. McKamey, and E. H. Lee, Scr. Metall. 24, 385 (1990).

17. T. Takasugi and O. Izumi, Acta Metall. 34, 607 (1986).

18. N. Masahashi, T. Takasugi, and O. Izumi, Metall Trans. A 19A, 353 (1988).

19. O. Izumi and T. Takasugi, J. Mater. Res. 3, 426 (1988).

20. T. Takasugi, N. Masahashi, and O. Izumi, Scr. Metall. 20, 1317 (1986).

21. N. Masahashi, T. Takasugi, and O. Izumi, Acta Metall. 36, 1823 (1988).

22. T. Takasugi and O. Izumi, Scr. Metall. 19, 903 (1985).

23. A. K. Kuruvilla, S. Ashok, and N. S. Stoloff, in Proceedings of the Third International Congress on Hydrogen in Metals, Vol. 2, 1982), p. 629.

24. A. K. Kuruvilla and N. S. Stoloff, Scr. Metall. 19, 83 (1985).

25. G. M. Camus, N. S. Stoloff, and D. J. Duquette, Acta Metall. 37, 1497 (1989).

26. C. T. Liu and M. Takeyama, Scr. Metall. 24, 1583-86 (1990).

27. C. T. Liu, C. L. Fu, E. P. George, and G. S. Painter, ISIJ Int. (October 1991).

28. C. T. Liu and E. P. George, Scr. Metall. 24, 1285 (1990).

29. C. T. Liu and E. P. George, pp. 527-32 in ref. 4 (1991).

30. D. J. Gaydosh and M. V. Nathal, Scr. Metall. 24, 1281 (1990).

31. R. J. Lynch, L. A. Heldt, and W. W. Milligan, Scr. Metall. 25, 2147 (1991).

32. M. Shea, A. Castagna, and N. S. Stoloff, p. 607 in ref. 4 (1991).

33. A. Castagna and N. S. Stoloff, Scr. Metall. 26, 673 (1992).

34. N. S. Stoloff, unpublished results, Rensselaer Polytechnic Institute (1992).

35. C. T. Liu, p. 321 in ref. 6 (1992).

36. C. T. Liu, V. K. Sikka, and C. G. McKamey, "Alloy Development of FeAl Aluminide Alloys for Structural Use in Corrosive Environments," ORNL Report, Martin Marietta Energy Systems, Inc., Oak Ridge Natl. Lab., Oak Ridge, TN, 1993 (unpublished).

37. C. T. Liu, Scr. Metall. 25, 1231 (1991).

38. C. T. Liu, C. L. White, and J. A. Horton, Acta Metall. 33, 213 (1985).

39. T. Takasugi, E. P. George, D. P. Pope, and O. Izumi, Scr. Metall. 19, 551 (1985).

40. T. Ogura, S. Hanada, T. Masumoto, and O. Izumi, Metall. Trans. 16A, 441 (1985).

41. C. T. Liu, Scr. Metall. 27, 25 (1992).

42. C. T. Liu and W. C. Oliver, Scr. Metall. 25, 1933 (1991).

43. T. Takasugi and O. Izumi, Acta Metall. 33, 1247 (1985).

44. T. Takasugi, O. Izumi, and N. Masahashi, Acta Metall. 33, 1259 (1985).

45. A. I. Taub, C. L. Briant, S. C. Huang, K. M. Chang, and M. R. Jackson, Scr. Metall. 20, 129 (1986).

46. A. I. Taub and C. L. Briant, p. 343 in ref. 2 (1987).

47. A. I. Taub and C. L. Briant, Acta Metall. 35, 1597 (1987).

48. V. Vitek and S. P. Chen, Scr. Metall. 25, 1237 (1991).

49. V. Vitek, S. P. Chen, A. F. Voter, J. J. Kruisman, and J. Th. M. De Hosson, "Grain Boundary Chemistry and Intergranular Fracture," edited by G. S. Was and

S. M. Bruemmer, Mater. Sci. Forum 46, 237 (1989).

50. M. Yan, V. Vitek, and G. J. Ackland, p. 335-70 in ref. 8 (1992).

51. J. J. Kruisman, V. Vitek, and J. Th. M. De Hosson, Acta Metall. 36, 2729 (1989).

52. T. Takasugi and O. Izumi, Acta Metall. 34, 607 (1986).

53. N. Masahashi, T. Takasugi, and O. Izumi, Metall. Trans. 19A, 353 (1988). 
54. E. P. George, C. T. Liu and D. P. Pope, Scr. Metall. 27, 365-70 (1992).

55. T. Takasugi, H. Suenaga, and O. Izumi, J. Mater. Sci. 26, 1179 (1991).

56. C. Nishimura and C. T. Liu, Scr. Metall. 27, 1307-11 (1992).

57. C. Nishimura and C. T. Liu, Scr. Metall. 25, 791 (1991).

58. A. Aoki and O. Izumi, Nippon Kinzoku Gakkaishi 43, 1190 (1979).

59. C. T. Liu, Martin Marietta Energy Systems, Inc., Oak Ridge Natl. Lab., Oak Ridge, TN, August 1992 (unpublished).

60. C. T. Liu and V. K. Sikka, J. Met. 38, 19 (1986).

61. C. T. Liu, V. K. Sikka, J. A. Horton, and E. H. Lee, "Alloy Development and Mechanical Properties of Nickel Aluminide (Ni3Al) Alloys," ORNL-6483, Martin Marietta Energy Systems, Inc., Oak Ridge Natl. Lab., Oak Ridge, TN, August 1988.

62. C. T. Liu, U.S. Patent No. 5,108,700 April 1992).

63. C. T. Liu, in Micon 86 (ASTM, Philadelphia, PA, 1988) p. 222.

64. A. I. Taub, K.-M. Chang, and C. T. Liu, Scr. Metall. 20, 1613 (1986).

65. B. G. Gieseke and V. K. Sikka, Martin Marietta Energy Systems, Inc., Oak Ridge Natl. Lab., Oak Ridge, TN, August 1992 (unpublished).

66. Y. F. Han, S. H. Li, S. Ma, and Y. N. Tan, paper presented at First Pacific P.im International Conference on Advanced Materials and Processing, Hongzhou, China, June 23-27, 1992 (unpublished).

67. K. Vedula, V. Pathare, I. Aslamidis, and R. H. Titran, pp. 411-421 in Ref. 1.

68. J. L. Smialek, Metall. Trans. A 9A, 309 (1978).

69. R. Darolia, J. Met. 43(3), 44 (1991).

70. R. D. Noebe, R. R. Bowman, and M. V. Nathal, accepted for publication in Int. Met. Rev. (1993).

71. J. A. Nesbitt, E. J. Vinarcik, C. A. Barrett and J. Doychak, Mater. Sci. Eng. A153, 56166 (1992).

72. C. A. Rarrett, Oxid. Met. 30, 361 (1988).

73. A. Ball and R. E. Smallman, Acta Metall. 14, 1517 (1966).

74. N. J. Zaluzec and H. L. Fraser, Scr. Metall. 8, 1049 (1974).

75. I. Baker and E. M. Schulson, Metall. Trans. A 15A, 1129 (1984).

76. E. P. George and C. T. Liu, J. Mater. Res. 5, 754 (1990).

77. K. H. Hahn and K. Vedula, Scr. Metall. 23, 7 (1989).

78. E. M. Grala, in Mechanical Properties of Intermetallic Compounds, edited by J. H. Westbrook (Wiley, New York, 1960), p. 368.

79. R. Darolia, D. F. Lahrman, and R. D. Field, Scr. Metall. 26, 1007 (1992).

80. C. T. Liu, J. A. Horton, E. H. Lee, and E. P. George, "Alloying Effects on Mechanical and Metallurgical properties of NiAl," Martin Marietta Energy Systems, Inc., Oak Ridge Natl. Lab., ORNL Report, Oak Ridge, TN, 1993 (unpublished).

81. J. E. Hack, J. M. Brzeski, and R. Darolia, Scr. Metall. 27, 1259 (1992).

82. R. E. Reed-Hill in Physical Metallurgy Principles, 2nd ed. (Van Nostrand, New York, 1973).

83. R. R. Bowman, R. D. Noebe, S. V. Raj, and I. E. Locci, Metall. Trans. A 23A, 1493 (1992).

84. R. Jayaram and M. K. Miller, Surf. Sci. 266, 310 (1992).

85. R. Darolia, General Electricm Aircraft Engines, 1992 (private communication).

86. J. D. Rigney and J. J. Lewandoski, Mater. Sci Eng. A149, 143-51 (1992).

87. R. D. Noebe, C. L. Cullers, R. R. Bowman, J. Mater. Res. 7, 605 (1992).

88. D. F. Lahrman, R. D. Field, and R. Darolia, p. 603 in ref. 4 (1991).

89. H. Lipsitt, p. 351 in ref. 1 (1985).

90. K. S. Kumar and S. A. Brown, Philos. Mag. A 65, 91 (1992).

91. E. P. George, J. A. Horton, W. D. Porter, and J. H. Schneibel, J. Mater. Res. 5, 1639 (1990).

92. S. L. Draper, P. K. Brindley, and M. V. Nathal, Metall. Trans. 23 A 2541 (1992).

93. D. B. Miracle, D. L. Anton, and J. A. Graves, in Intermetallic Matrix Composite II, Vol. 273 (MRS, Pittsburgh, PA, 1992).

94. G. M. Stocks and A. Gonis, "Alloy Phase Stability and Design," NATO ASI Series, Vol. 163 (Kluwer Academic Publishers, Boston, MA, 1992).

95. C. L. Fu and M. H. Yoo, Philos. Mag, Leit. 62, 159 (1990).

96. M. H. Yoo and C. L. Fu, ISIJ Int. 31, 1049 (1991).

97. M. H. Yoo, C. L. Fu, and J. K. Lee, p. 545 in ref. 4 (1991). 
98. C. L. Fu and M. H. Yoo, p. 155 in ref. 8 (1992).

99. M. H. Yoo and C. L. Fu, Martin Marietta Energy Systems, Inc., Oak Ridge Natl. Lab., Oak Ridge, TN, 1992 (private communication).

100. H. Inui, M. H. Oh, A. Nakamura, and M. Yamaguchi to be published in Acta Metall. (1993).

101. M. Yamaguchi and H. Inui, p. 217 in ref. 8 (1992).

102. Y-W. Kim, p. 777 in ref. 4 (1991), and Acta Metall. 40, 1121 (1992).

103. T. Fujiwara, A. Nakamura, M. Hosomi, S. R. Nishitani, Y. Shirai, and M. Yamaguchi, Philos. Mag. A 61, 591 (1990).

104. Y-W. Kim, Universal Energy Systems, Inc., 1992 (private communication).

105. K. S. Chan and Y-W. Kim, Trans. Metall. A 23A, 1663 (1992).

106. V. K. Sikka, J. T. Mavity, and K. Anderson, Mater. Sci. Eng. A-153, 712 (1992).

107. V. K. Sikka, Oak Ridge Natl. Lab., Oak Ridge, TN, 1992 (private communication).

108. R. Darolia, D. F. Lahrman, R. D. Field, J. R. Dobbs, K. M. Chang, E. H. Goldman, and D. G. Konitzer, p. 679 in ref. 8 (1992).

109. M. Yamaguchi, Kyoto University, Kyoto, Japan, 1992 (private communication).

110. P. Meschter and D. S. Schwartz, J. M.t. 41, 52-55 (1989).

111. S. Maloy, A. H. Heuer, J. J. Lewandowski, and J. Petrovic, J. Am. Ceram. Soc. 74, 2704 (1991).

112. T. Fujiwara, K. Yasuda, and H. Kodama, pp. 633-37 in ref. 7 (1991).

113. D. L. Anton and D. M. Shah, pp. $361-71$ in ref. 3 (1989).

114. M. Takeyama and C. T. Liu, Mater. Sci. Eng. A132, 61 (1991).

115. J. D. Livingston, Phys. Status. Solidi A 131, 415 (1992).

116. Kanthal Super Handbook, Kanthal Furnace Products, 1986.

117. W. J. Buehler and F. I. Wang, Ocean Eng. 1, 105-20 (1986).

118. I. M. Schetky, Sci. Am. 241, 74-82 (1979).

119. C. T. Liu, H. Kunsmann, K. Otsuka, and M. Wuttig, ed., "Shape-Memory Materials and Phenomena-Fundamental Aspects and Applications," in Proceedings of Materials Research Society Symposium (MRS, Pittsburgh, PA, 1992).

120. E. P. George, C. T. Liu, C. J. Sparks, Ming-Yuan Kao, J. A. Horton, H. Kunsmann, and T. King, pp. $121-28$ in ref. 119 (1992).

121. A. Hutton, J. Met. 44(3), 11 (1992).

122. M. Sagawa, S. Hirosawa, H. Yamamoto, S. Fujimura, and Y. Matsura, Jpn. J. Appl. Phys. 26, 785 (1987).

123. K. S. Kumar, "Silicides Technology and Applications," in Intermetallic Compounds: Principles and Practice, edited by J. H. 'Westbrook and R. L. Fleischer (John Wiley and Sons, New York, 1993).

\section{DISCLAIMER}

ccount of work sponsored by an agency of the United States States Government nor any agency thereof, nor any of their Government. Neither the United States Government nor any agency legal liability or responsiemployees, makes any warranty, express or implied, or asu information, apparatus, product, or bility for the accuracy, completeness, or usefulness of any ining privately owned rights. Referprocess disclosed, or represents that its use would not infrer service by trade name, trademark, ence herein to any specific commercial product, process, or ser imply its endorsement, recommanufacturer, or otherwise does not necessarily constinte or any agency thereof. The views mendation, or favoring by the United States Governmentarily state or reflect those of the and opinions of authors expressed herein do not

United States Government or any agency thereof. 

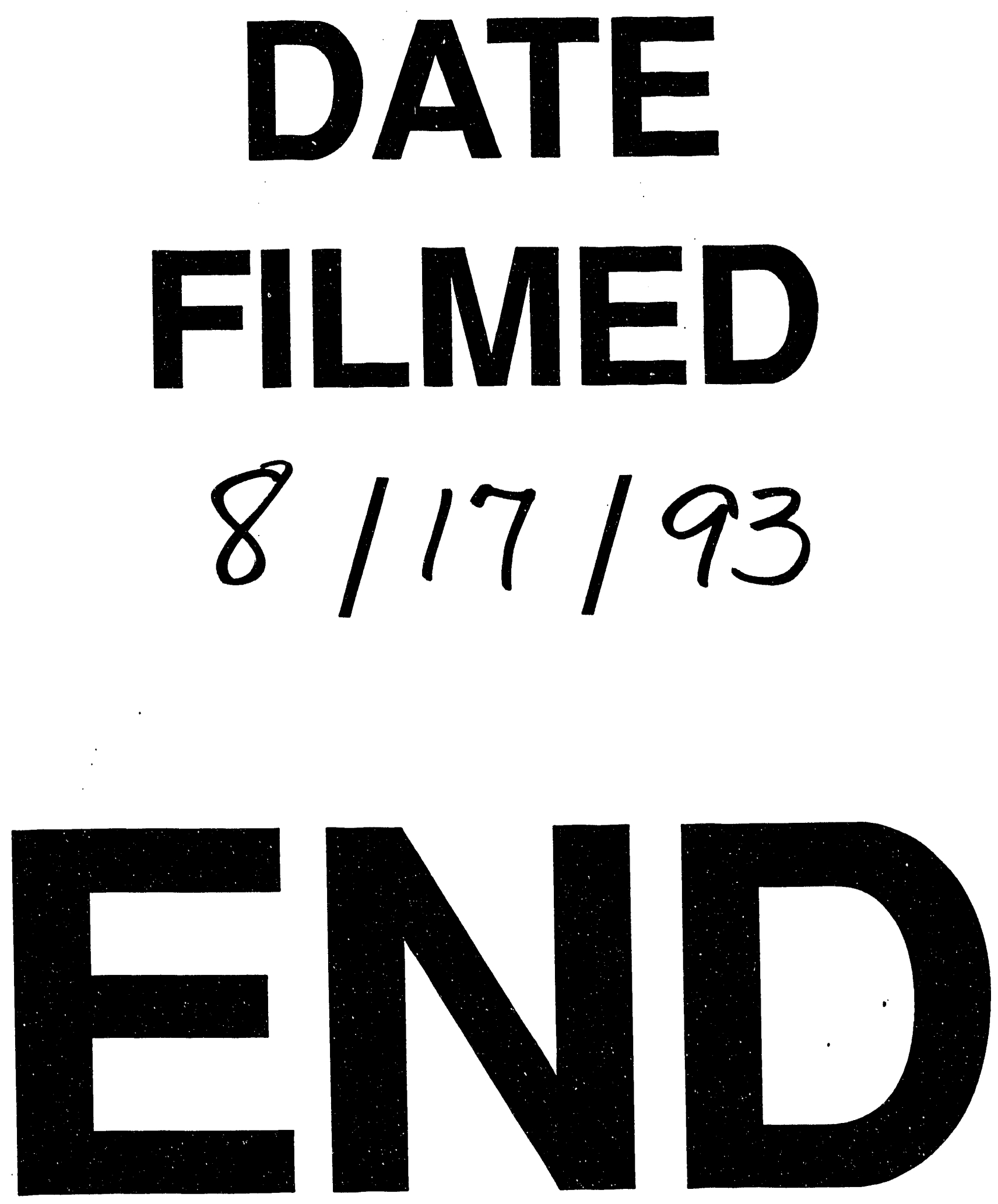
